\title{
DO GUARANTEED-LOW-PRICE POLICIES GUARANTEE HIGH PRICES, AND CAN ANTITRUST RISE TO THE CHALLENGE?
}

\author{
Aaron S. Edlin
}

\section{TABLE OF CONTENTS}

I. THE ECONOMICS OF PRICE-MATCHING POLICIES ..................................................... 536

A. Overview....................................................................................................... 536

B. A Simple Model of Price Matching....................................................................... 539

C. Limitations of Price Matching ............................................................................................ 543

D. The Potential Social Cost of Price Matching.............................................................. 547

E. A Simple Model of Price Matching....................................................................... 550

II. PRICE MATCHING UNDER THE SHERMAN ACT................................................................ 553

A. Horizontal Agreement ....................................................................................... 553

B. Vertical Agreement......................................................................................................... 555

III. DOES PRICE MATCHING CONSTITUTE ILlEgal PRICE DISCRIMINATION? .................. 558

A. The Meeting-Competition Defense .................................................................... 560

r. Standard Oil............................................................................................. 561

2. The Meeting-Competition Defense Applied to Price Matching..................... $\quad 563$

3. The Meeting-Competition Defense Generally............................................... 565

B. Is Price Discrimination the Culprit? ................................................................ 565

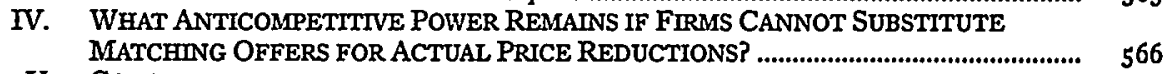

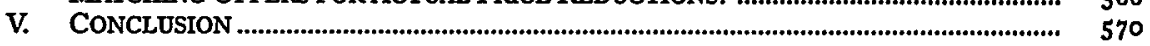

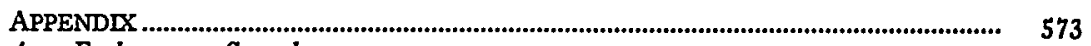

A. Endogenous Search ............................................................................................... 573

B. General Demand .................................................................................................... 574 


\title{
DO GUARANTEED-LOW-PRICE POLICIES GUARANTEE HIGH PRICES, AND CAN ANTITRUST RISE TO THE CHALLENGE?
}

\author{
Aaron S. Edlin*
}

\begin{abstract}
Price-matching policies can be highly anticompetitive. They allow firms to raise their prices above competitive levels by discriminating in price between informed and uninformed customers. The resulting high prices can persist even when new firms enter the industry, a fact that gives price matching the potential to be much more socially costly than an ordinary monopoly or cartel. At the same time, widespread entry implies that the agreement among sellers that is typical of a Sherman Act price-fixing case may be absent. In this Article, Professor Edlin argues that there is nonetheless an analogy between a seller offering (and agreeing) to match a price for a buyer and other buyerseller agreements that violate the Sherman Act. He also considers a wholly new avenue for attacking price matching, asking whether the price discrimination involved in matching violates the unfair-competition or price-discrimination laws. In so doing, Professor Edlin examines whether price matchers should be able to protect themselves from such an attack with a "meeting competition" defense. Breaking with conventional wisdom, he concludes that the defense should be rejected in cases in which meeting competition may significantly injure competition among sellers.
\end{abstract}

Sellers increasingly "guarantee" their low prices with pricematching offers. ${ }^{1}$ The Sports Authority, for example, advertises that

* Associate Professor of Economics, University of California at Berkeley; Faculty Research Fellow, Program in Law and Economics, National Bureau of Economic Research; Senior Economist, President's Council of Economic Advisers. The views in this Article do not necessarily reflect those of the Council of Economic Advisers.

For helpful comments, I thank the participants in seminars at Harvard Law School, the Department of Justice, Georgetown Law Center, Michigan Law School, Rutgers Economics Department, Texas A\&M Economics Department, University of Texas Economics Department, and in meetings of the American Law and Economics Association. I would particularly like to thank Ian Ayres, Douglas Baird, William Baxter, Alexander Dyck, Dorothy Edlin, Mario Epelbaum, Steven Goldman, Joseph Grundfest, Gillian Hadfield, Louis Kaplow, Peter Menell, Barry Nalebuff, Alan Schwartz, Lisa Sherman, Joseph Stiglitz, and Eric Talley. I gratefully acknowledge the financial support of the National Science Foundation and Olin Foundation. For research assistance, $I$ thank Eric Emch, Peter Klein, and Karrie Johnson.

1 As one article notes:

Price-matching pledges proliferated in the early Ig80s .... The tactic was first used in the cutthroat consumer-electronics, auto-supply and general discount-store businesses, but it spread. So many stores began using the policies as a marketing pitch that mainstream merchants had little choice but to start making the claim, too.

Francine Schwadel, Who Wins with Price-Matching Plans?, Wall ST. J., Mar. I6, I989, at Br; see also Ed Christman, Super Sonic: More Chains, Indie Stores Getting Into the Megastore Mode in '93, BILLBOARD, Jan. 16, I993, at 50 (explaining Musicland's plan to offer price matching at its new Media Play chain of outlet stores); Robert A. Cronkleton, Custom Window Coverings Are Three Day Blinds Specialty, KaN. CiTy STAR, Apr. 12, 1995, at B3 (describing the operations of the country's largest "window covering specialists," including their guarantee to match prices on comparable blinds); Steve Law, Sportmart Wades into Local Sporting Goods Market, Bus. J. PORTLAND, June I4, I993, at I (explaining how a sporting-goods "superstore" planned to use a price-matching policy to establish itself in a new market); Nancy Millman, Price Wars Spreading 
"[i]f you ever find a lower competitor's price, we'll match it! Hassle free!"2 The Good Guys!, a consumer-electronics store, likewise promises not to be undersold. ${ }^{3}$ Price-matching policies have proliferated in a variety of retail markets, including computers, furniture, windows, sporting goods, textbooks, consumer electronics, tires, automobiles, and in-flight sales. ${ }^{4}$ The tactic extends beyond retail sales and is employed by manufacturers and other input suppliers. ${ }^{5}$ Recently, interest-rate matching has crept into the vast market for loans, ${ }^{6}$ and price matching

to Once-Sacred Funeral Industry, CHI. TRIB., Mar. 2x, I994, at $\mathrm{Cr}$ (discussing how an established firm in the Chicago funeral home industry instituted a price-matching policy to counter an aggressive new entrant).

2 The Sports Authority, Advertisement, N.Y. TMMES, Mar. 23, I995, at B20.

3 See The Good Guys!, Advertisement, SAN Jose MERCURY NEwS, Mar. 26, 1993, at I5A.

4 For sellers with price-matching policies in these markets, see CompUSA, Advertisement, PHILA. INQUIRER, Aug. I4, I994, at B3 (computers); Roberds, Advertisement, ATLANTA J.CoNsr., Aug. 4, I994, at CI (furniture); Variety Windows and Exteriors, Advertisement, WASH. POST, Nov. 5, I995, TV Week, at 60 (windows); The Sports Authority, supra note 2 (sporting goods); Campus Textbook Exchange, Advertisement, DAIly CALIFoRNIAN, Aug. 28, 1995, at 5 (textbooks); Circuit City, Advertisement, WASH. PoST, July 4, I994, at CI4 (electronics); Wolf Camera \& Video, Advertisement, ATLANTA J.-CoNST., Aug. 4, 1994, at E8 (cameras and video equipment); and Merchant's, Advertisement, WASH. POST, Nov. 5, I995, at D5 (automobile service and parts). A catalog carried by United Airlines even offers such a guarantee on in-flight sales. See Hrgh Street EMPorrum, Catalog, Summer r997.

5 See, e.g., NCA Computer Products, Advertisement, SAN Jose Mercury News, Sept. 4, I 995, at 3A (offering "guaranteed lowest prices" on computer systems and other products). AMP, the world's largest electronics-connector manufacturer with $\$ 3.3$ billion in sales in I992, uses price-matching policies both through its distributors and through its direct sales force. Although AMP is the dominant firm in its market, in recent years it has had to fend off competition from price-cutting newcomers in Asia. Price matching, or "meeting competition" as it is sometimes called in distribution, is one strategy that AMP has used to maintain market share. See Barbara Jorgensen, AMP Diversifies to Continue Growing, ELECTRONIC Bus. BuYER, Oct. 1993, at 78, 80-8I. Sundial Homes offered a guaranteed-lowest-price policy on 118 newly built homes in the Toronto area, promising to match offers on comparably sized homes with similar features and lot size. See Vincent Blain, Eighteen-Hole Links Proposed for Community, Toronto STAR, May 6, I995, at Fr.

Meet-or-release clauses, which are similar to price-matching policies, have reportedly been used in wholesale markets for salt, chlor-alkali, and lead fuel additives. See International Salt Co. v. United States, 332 U.S. 392, 396 (I947); E.I. du Pont de Nemours v. FTC, 729 F.2d 128, I34 (2d Cir. I984); United States v. FMC Corp., 306 E. Supp. Iro6, Irr2 (E.D. Pa. I969). According to Steven Salop, the defendants in $d u$ Pont all offered meet-or-release clauses, although these clauses were not litigated in the case. See Steven C. Salop, Practices That (Credibly) Facilitate Oligopoly Co-ordination, in New Developments in the ANAlysis OF MARKet StruCture 265, 287 n.37 (Joseph E. Stiglitz \& G. Frank Mathewson eds., I986). Under a meet-or-release clause, if a buyer is offered a lower price by another seller, it cannot accept the offer without first giving the initial seller a chance to match the offer. Only if the initial seller refuses is the buyer released from her obligations. Salop also reported that some firms offer no-release policies that require a seller to match all competitors' offers. See id. at 280-8x.

6 Bank of the West advertises an interest-rate-matching policy on the radio. See Aaron S. Edlin \& Eric R. Emch, The Welfare Losses from Price Matching Policies I n.2 (September I997) (unpublished manuscript, on file with the Harvard Law School Library). 
has become common among market makers on the National Association of Securities Dealers Automated Quotation System (NASDAQ). ${ }^{7}$

On its face, a price-matching policy seems the epitome of cutthroat competition: what could be more competitive than sellers' guaranteeing their low prices by promising to match the prices of any competitor? However, appearances notwithstanding, guaranteeing low prices turns out to be a good substitute for actually having low prices. Under the cover of a matching offer, a firm can price-discriminate by charging high posted prices to poorly informed buyers, while still enticing savvy shoppers with the low prices promised by the matching offer. ${ }^{8}$ In addition, rival firms are discouraged from offering low prices to undercut a price matcher, because the price matcher's guaranteed-lowprice policy prevents it from being undercut.9 For these two reasons, when price matching becomes pervasive, few low prices may remain even for the most savvy shopper.

7 See infra p. 572 \& n.I65; see also Securities and Exchange Commission, Report Pursuant to Section 2 I(a) of the Securities Exchange Act of 1934 Regarding the NASD and the NASDAQ Market I4-15 (Aug. 8, 1996).

8 This argument does not require that all savvy customers be retained, only that some be retained. If some are retained because of the matching offer, a price matcher will charge higher prices than an otherwise identical non-matcher. See infra section I.C.

9 Several authors, beginning with Salop, have emphasized the effect of price matching on rivals' incentives. See, e.g., Salop, supra note 5, at 279-83; Terrence M. Belton, $A$ Model of Duopoly and Meeting or Beating Competition, 5 INT'L J. INDUS. ORG. 399, 40I-07 (I987); Christopher Doyle, Different Selling Strategies in Bertrand Oligopoly, 28 ECON. LETTERS 387, 387-90 (1988).

Kenneth Corts, on the other hand, argues that the competitive equilibrium can be restored in a price-matching model in which stores can offer both a price that can be matched or beaten and a final price that cannot be matched or beaten. Corts allows this final price to be an arbitrary function of other firms' matchable prices. See Kenneth S. Corts, On the Robustness of the Argument That Price-Matching Is Anti-Competitive, 47 ECON. LETTERS 4I7, 4I9-20 (I995); see also Morten Hviid \& Greg Shaffer, Do Low-Price Guarantees Facilitate Collusion? 4-6 (May I994) (unpublished manuscript, on file with the Harvard Law School Library). This argument, however, rests on the fact that final prices are unmatchable in their models. Monopoly pricing is restored if one relaxes their assumptions and allows matching of both final prices and posted prices. See Doyle, supra, at 390 . Anecdotal evidence offered by participants in a Harvard Law School seminar suggests that, in practice, price beaters or matchers will beat or match final prices, not just advertised prices. Consider a price beater that posts a price of $\$ 250$, when a second store posts a price of $\$ 200$. If the price beater offers to beat a lower price by 10\% of the difference, it is effectively offering to sell at \$I95 to those "in the know." According to a number of buyers, if the second store is a price matcher or beater, they will match or beat $\$ 195$, not just $\$ 250$, despite the fact that advertisements often indicate otherwise. This is not surprising because sellers have an incentive, as this Article explains, to match any legitimate (not fictitious) offer.

Other scholars have developed different models of price matching. See, e.g., David T. Levy \& Daniel A. Gerlowski, Competition, Advertising, and Meeting Competition Clauses, 37 EcoN. LETTERS 2 I7, 2I7-I9 (I99I) (recognizing the price-discrimination function of meetingcompetition clauses, although erroneously concluding that they necessarily lead to competitive prices for informed customers); Z. John Zhang, Price-Matching Policy and the Principle of Minimum Differentiation, 43 J. INDUS. ECON. 287, 293-96 (I995) (analyzing a model of product differentiation in which price-matching policies encourage firms to produce similar products). 
Antitrust is the traditional bulwark against such noncompetitive outcomes. ${ }^{10}$ Price matching, however, poses a peculiar challenge to antitrust policy because, as this Article demonstrates, price matchers can charge high prices without forming collusive agreements or having the power to raise market prices unilaterally. ${ }^{11}$ These features make pricematching policies difficult to attack under the Sherman Act, ${ }^{12}$ yet

10 Because "[m]arkets left to themselves sometimes produce inefficient outcomes[] . . . [p]ublic antitrust enforcement complements market forces by supporting conditions conducive to competition." ECONOMic RePORT OF THe PReSIDENT 192-93 (r997). According to the Supreme Court, "the sole aim of antitrust legislation is to protect competition." Gordon v. NYSE, 422 U.S. 659, 689 (1975). Not surprisingly, judges and legislators have interpreted "protecting competition" in a variety of ways. Most commentators hold that the primary purpose of antitrust legislation is to protect consumer welfare. See, e.g., RoBert H. BORK, The ANTitruSt PARAdoX 51, 56-66 (I978) (arguing that protecting consumer welfare has historically been the dominant rationale behind antitrust and is the only legitimate goal of antitrust legislation). At times, however, other goals have been evident both in congressional and in judicial proceedings. Judge Learned Hand wrote of the antitrust laws that "it has been constantly assumed that one of their purposes was to perpetuate and preserve, for its own sake and in spite of possible cost, an organization of industry in small units which can effectively compete with each other." United States v. Aluminum Co. of Am., I48 F.2d 4I6, 429 (2d Cir. I945); see also Thomas J. DiLorenzo, The Origins of Antitrust: An Interest-Group Perspective, 5 INT'L REV. L. \& ECON. 73, 74-76 (I985) (interpreting the Sherman Act as interest-group legislation designed to transfer wealth from big business to small merchants and farmers); Robert $\mathrm{H}$. Lande, Wealth Transfers as the Original and Primary Concern of Antitrust: The Efficiency Interpretation Challenged, 34 HASTINGS L.J. 65, 68 (1982) (finding a major goal of antitrust to be the prevention of unfair wealth redistributions "from consumers to firms with market power"); David Millon, The Sherman Act and the Balance of Power, 6I S. CAL. L. REV. I2 I9, I287-92 (1988) (viewing the original purpose of the Sherman Act to be the protection of democratic institutions from concentrated economic power).

11 This possibility contradicts Joseph Simons's assertion that unconcentrated industries should suffer no anticompetitive effects either from most-favored-customer clauses or from pricematching policies. See Joseph J. Simons, Fixing Price with Your Victim: Efficiency and Collusion with Competitor-Based Formula Pricing Clauses, I7 HoFsTRA L. REv. 599, 600, 617, 639 (1989). But see I.P.L. Png \& D. Hirshleifer, Price Discrimination Through Offers to Match Price, $60 \mathrm{~J}$. Bus. 365, 372-74 (1987) (demonstrating in a mathematical price-matching model that entry actually causes prices to rise for intermediate buyers if informed buyers have a more elastic demand for the product than uninformed ones). Png and Hirschleifer do not examine the welfare consequences of barring price-matching offers. Rather, they are concerned with rebutting the conventional wisdom that competition eliminates price discrimination. They show that, in a pricematching model, competition can actually facilitate price discrimination.

12 Section I of the Sherman Act prohibits "[e]very contract, combination in the form of trust or otherwise, or conspiracy, in restraint of trade or commerce among the several States, or with foreign nations." I5 U.S.C. § I (I994). This section makes agreements to fix prices per se illegal, regardless of the prices charged or whether the group has collective monopoly power. See United States v. Socony-Vacuum Oil Co., 310 U.S. 150, 2 ro-14, 219-20 (1940) (upholding a jury instruction stating that an agreement to raise prices was per se illegal regardless whether the prices were "reasonable" or whether some market sales were still subject to competitive forces); see also United States v. Trenton Potteries, Co., 273 U.S. 392, 396-98 (1927) (holding that agreements to fix prices may be in themselves unreasonable restraints of trade without the necessity of determining whether a particular fixed price is reasonable or unreasonable); United States v. TransMissouri Freight Ass'n, I66 U.S. 290, 339-40 (I897) (dismissing as irrelevant the contention that Congress intended the Sherman Act to prohibit only unreasonable restraints of trade, notwithstanding the language of the Act).

In contrast, section 2 of the Sherman Act declares a felon "[e]very person who shall monopolize, or attempt to monopolize ... any part of the trade or commerce among the several States, or 
ironically give these policies the potential to be much more socially costly than the price-fixing cartels that are per se illegal. ${ }^{13}$ This observation suggests that antitrust scholars and policymakers (including judges) may need to shift from their traditional focus on market power and collusive agreements among sellers. ${ }^{14}$

Instead of focusing on agreements among sellers, which this Article shows are unnecessary for price matching to be anticompetitive, this Article concentrates on what is necessary: an agreement between a buyer and seller to have the seller match the price of another seller. ${ }^{15}$

with foreign nations." I5 U.S.C. $\S 2$ (1994). Unilateral action may therefore violate this section, but the violator must have sufficient market power such that his plan could bring anticompetitive effects. "The offense of monopoly under $\S 2$ of the Sherman Act has two elements: (I) the possession of monopoly power in the relevant market and (2) the willful acquisition or maintenance of that power as distinguished from growth or development as a consequence of a superior product, business acumen, or historic accident." Eastman Kodak Co. v. Image Technical Servs., Inc., 504 U.S. 45I, 48 I (I992) (quoting United States v. Grinnell Corp., 384 U.S. 563, 570-7 I (I966)) (internal quotation marks omitted).

13 Because sellers do not need to reach or sustain an agreement, price matching has the potential to produce anticompetitive results in a wider variety of markets than do cartels. Also, because high prices can be sustained even with entry, markets with price matching are more wasteful than those with cartels. See infra section I.B (explaining that profits are dissipated from overentry).

14 Previous legal analysis has tried to fit price matching into a traditional antitrust paradigm as a "facilitating practice," a practice that helps sellers to maintain a possibly unspoken agreement to charge high prices. These arguments did not address the power of price matching to remove the need for agreement to raise prices, or its tendency to be more socially costly than cartels and to facilitate price discrimination. See Ian Ayres, How Cartels Punish: A Structural Theory of SelfEnforcing Collusion, 87 CoLUM. L. REv, 295, 296, 316 \& n.Ior (1987) (explaining that "[t]0 collude effectively, firms must be able ( $I$ ) to reach an agreement, (2) to detect breaches of the agreement, and (3) to punish firms that breach," and observing that price-matching policies help with the latter two conditions); see also Donald S. Clark, Price-Fixing Without Collusion: An Antitrust Analysis of Facilitating Practices After Ethyl Corp., I983 WIS. L. REv. 887, 901-02, 932-35 (arguing that, in concentrated markets, meet-or-release clauses or generalized most-favored-nation clauses, which include a price-matching pledge, facilitate coordination by penalizing discounting); Mark T.L. Sargent, Economics Upside-Doven: Low-Price Guarantees as Mechanisms for Facilitating Tacit Collusion, I4I U. PA. L. REv. 2055, 2075-82 (I993) (arguing that price beating is a potent facilitating practice because it allows one firm to send a powerful signal to others of its desire to collude when it raises its prices and steals all the other firms' business with its price-beating offer).

In addition, price matching does not fit into the traditional Chicago School paradigm, which finds a tension in antitrust between allocative and productive efficiency. The traditional tension is that monopolies may lead to allocative inefficiency because they price above marginal cost, but may also be productively efficient because of economies of scale. In contrast, price matching may cause prices to rise far above marginal cost even in markets with widespread entry, and in these markets average costs will be high. See infra section I.D. For discussion of the traditional Chicago School view of this tension, see BORK, cited above in note 10, at 90-106, and Herbert Hovenkamp, Antitrust Policy After Chicago, 84 MrCH. L. Rev. 2 I3, 226-33 (I g85).

15 At least three other authors have suggested focusing on buyer-seller agreements under a Sherman Act section I analysis in closely related contexts. See 6 PHILlP E. AREedA, ANTITRUST LAW II I435e, at 230-3I n.23 (I986) (examining these agreements in the context of most-favored-customer clauses, which are discussed in section I.E below); Sargent, supra note I4, at 2 104 -08 (examining these agreements in the context of price-beating pledges, which are discussed below in note 29); Simons, supra note II, at 630-3I (examining these agreements in the 
At first, it may seem odd to focus on a buyer-seller agreement as the source of a reduction of competition among sellers. However, tying sales, exclusive dealing agreements, retail price maintenance, and territorial restrictions - all buyer-seller agreements - can violate section $x$ of the Sherman Act when courts find that they lessen competition among buyers or sellers. ${ }^{16}$ By analogy, the buyer-seller agreements involved in price matching are likewise suspect under section $I$ if they reduce competition. Part II of this Article argues that these buyerseller agreements are in fact what drives price matching's anticompetitive potential, and that banning matching sales under the Sherman Act would give sellers the incentive to quote low prices in the first place to avoid being undercut.

This Article also proposes a new legal approach to price matching. Because discriminating in price between informed and uninformed customers lies at the heart of the anticompetitive power of price matching, this Article explores whether the price discrimination involved in these policies violates federal or state statutes that prohibit price discrimination or unfair methods of competition. ${ }^{17}$ One central

context of long-term contracts with most-favored-customer clauses or meet-or-release clauses); see also United States v. Delta Dental, 943 F. Supp. I72, 174-80 (1996) (examining these agreements in the context of insurers' contracts with dentists).

16 On tying, see, for example, Northern Pac. Ry. Co. v. United States, 356 U.S. I, 5-7 (I958), and International Salt Co. v. United States, 332 U.S. 392 (1947). On exclusive dealing, see, for example, Standard Oil Co. v. United States, 337 U.S. 293, 294-3I4 (I949). On resale price maintenance, see, for example, Monsanto Co. v. Spray-Rite Serv. Corp., 465 U.S. 752, 76I-64 (1984), and Dr. Miles Med. Co. v. John D. Park \& Sons Co., 220 U.S. 373, 404-08 (IgrI). On territorial restrictions, see, for example, United States v. Arnold, Schwinn \& Co., 388 U.S. 365, 372-79 (I967). Although Continental T.V. v. GTE Sylvania, 433 U.S. 36 (I977), overruled the broad per se rule in Schwinn, the Court did "not foreclose the possibility that particular applications of vertical restrictions might justify per se prohibition," nor the possibility that vertical agreements might be illegal under a rule of reason standard. Id. at 58-59.

As section II.B of this Article discusses, the Chicago School believes that horizontal competition is rarely injured by vertical agreements such as tying sales, exclusive dealing, resale price maintenance, and territorial restrictions. See BORK, supra note Io, at $280-98$. But cf. Jonathan B. Baker, Vertical Restraints with Horizontal Consequences: Competitive Effects of "Most-

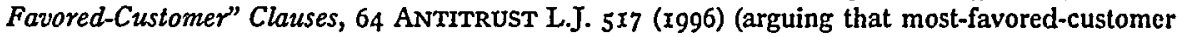
clauses can be used to facilitate horizontal collusion). Even if one takes the Chicago position, however, vertical agreements will violate section I of the Sherman Act in cases in which they actually do injure horizontal competition, as this Article claims price matching does.

17 In relevant part, the Clayton Act, as amended by section 2(a) of the Robinson-Patman Act, reads: "It shall be unlawful . . . to discriminate in price . . . where the effect of such discrimination may be substantially to lessen competition ... or prevent competition with any person who either grants or knowingly receives the benefit of such discrimination." I5 U.S.C. \& I3(a) (1994). Section 5(a) of the Federal Trade Commission (FTC) Act bans "unfair methods of competition," I5 U.S.C. $\S 45$ (a) (I994), which has been interpreted to include any discrimination violating section 2 (a) of Robinson-Patman. See FTC v. Motion Picture Adver. Serv. Co, 344 U.S. 392, 394-95 (r953); Standard Oil Co. v. FTC, 340 U.S. 23I, 239-42 (I95I); PHILlip AREedA \& Louis Kaplow, ANTITRUST ANALYSIS: PROBLEMS, TEXTS, AND CASES 153 (I988).

Many states have similar statutes banning price discrimination, see, e.g., CoNN. GEN. STAT. § 35-45 (r987); UTAH CODE ANN. § I3-5-3 (I996), and unfair competition, see, e.g., Colo. REV. STAT. \& 6-2-IO2 (I996); CONN. GEN. STAT. § 42-I IO(b) (I992). 
difficulty with such an approach is that discriminating in price has generally been regarded to be legal when the discriminatory low price is offered to meet a competitor's equally low price. ${ }^{18}$ The leading case establishing this "meeting competition" defense, Standard Oil Co. v. $F T C,{ }^{19}$ is premised on the assumption that meeting a competitor's price enhances competition among sellers. ${ }^{20}$

Part III of this Article considers whether meeting competition can ever be deemed anticompetitive behavior under the antitrust laws. Although the instinctive response is that it cannot, meeting competition is no more inherently competitive than the threat of mutually assured destruction was inherently destructive during the Cold War. Just as the United States and the Soviet Union each deterred the other from a nuclear first strike by credibly assuring the other of swift retaliation, ${ }^{21}$ a seller will be deterred from cutting prices if it is assured that other sellers will swiftly respond with their own price cuts. ${ }^{22}$ Widely advertised price-matching policies provide this assurance, and they do so cheaply because only well-informed customers get a reduced price. These observations suggest that a price matcher could still be charged with anticompetitive price discrimination even if it is merely meeting competition. A meeting-competition defense made sense in Standard Oil, given the Court's unchallenged assumption that meeting competition enhanced competition among sellers, but Part $\mathrm{WI}$ of this Article argues that the defense should not apply when the alleged competitive injury is among sellers. In such cases, meeting competition should be deemed anticompetitive whenever it promotes noncompetitive outcomes.

Neither of the legal theories that this Article proposes can be used to attack pure parallel pricing. Part IV, therefore, asks whether, in an age of electronic commerce, parallel pricing could pose the same com-

18 Section 2(b) of the Robinson-Patman Act, I5 U.S.C. § I3(b) (1994), allows a seller accused of violating section 2 the defense of showing that its price was set "in good faith to meet an equally low price of a competitor." Id. Section III.A of this Article explores whether such a defense applies. The meeting-competition defense probably exists by analogy in section 5 of the FTC Act. However, this defense may be more limited than under Robinson-Patman, because it is not explicitly included, and because the prohibitions of section 5 are broader than those of the Clayton and Sherman Acts and include "acts and practices, which when full blown, would violate those Acts." Motion Picture, 344 U.S. at 394-95; see also FTC v. Brovn Shoe Co., 384 U.S. 3I6, 320-2I (Ig66) ("[T]he Commission has broad powers to declare trade practices unfair. This broad power ... is particularly well established with regard to trade practices which conflict with the basic policies of the Sherman and Clayton Acts even though such practices may not actually violate these laws.").

19340 U.S. 23 I (195I).

20 See id. at 242.

21 See Greville Rumble, The Politics of Nuclear Defence 42, 7 I (I985) (explaining the idea of mutually assured destruction in nuclear deterrence).

22 See generally Jean TIROLE, The Theory OF Industrial ORganization 239-76 (Ig88) (explaining the general idea that, as the time of detection and response to price cuts becomes small, an increasing degree of tacit collusion becomes possible). 
petitive dangers as price matching. The Article concludes that, although parallel pricing will become increasingly troublesome as electronic commerce advances, price matching presents a greater threat to competition.

\section{The Economics of Price-Matching Policies}

\section{A. Overview}

A widely advertised price-matching offer can change the pricing incentives, both of the price matcher and of its rivals, in anticompetitive ways. The most obvious change is a dramatic reduction in rivals' incentives to cut prices: ${ }^{23}$ because price matchers automatically match any discount, rivals' price cuts no longer increase sales volume as much as they normally would. ${ }^{24}$

The change in incentives for the price matcher itself, which has generally been neglected, is more subtle, yet equally important. A seller with a matching policy has an incentive to raise its price above the competitive level with little, or at least lessened, fear of losing customers. The seller can retain some of the business of those customers that have the time and inclination to search for the lowest available price, because, even if the seller posts a high price, these customers can buy from the seller at the lowest available price by invoking the matching offer. ${ }^{25}$ At the same time, uninformed customers that do not

23 This idea is familiar and was first pointed out by Salop, supra note 5, at 272. This Article, however, refines it in several respects. See infra section I.E (comparing price matching with threats to lower price).

24 In the extreme case in which informed buyers care only about the price they must pay, and not the posted price, a rival will not attract any business from a price matcher by undercutting the matcher's price. More realistically, some buyers may view it as a hassle to go to a high-priced seller and invoke the seller's matching policy to get a lower price. If this "hassle cost" exceeds the "utility cost" to the buyer of switching from his favorite seller, this seller will not be able to hide behind his matching offer with respect to that buyer. Other buyers, whose switching costs are higher, will continue to patronize the high-priced price matchers and to invoke the matching pledge, regardless of the posted price. Morten Hviid and Greg Shaffer have recently argued convincingly that hassle costs mitigate the anticompetitive effects of price matching. See Morton Hviid \& Greg Shaffer, Hassle Costs: The Achilles' Heel of Price Matching Guarantees I2-24 (January I997) (unpublished manuscript, on file with the Harvard Law School Library). However, this Article will argue that Hviid and Shaffer overstate their case. See infra section I.C. As discussed below in section I.C, some firms may try to offer price-beating pledges or other bonuses in an effort to reduce or eliminate hassle costs. In other cases, such as the NASDAQ example, discussed below in note 165 , firms themselves may assume the hassle costs of price matching and thus make such costs invisible to consumers.

25 In some markets, the issue is not entirely a function of search and information. Because of luck or other factors, some buyers will be offered a lower price elsewhere; others will not. One familiar example is the market for new cars, in which it has been documented that, on average, dealers' offers depend on the race and sex of buyers. See Ian Ayres, Further Evidence of Discrimination in New Car Negotiations and Estimates of its Cause, 94 MrCH. L. REV. I09, 116 (1995); Ian Ayres \& Peter Siegelman, Race and Gender Discrimination in Bargaining for a New 
search for the lowest price end up paying the new, higher price and thereby give additional revenue to the price matcher. The price matcher can thus profitably price-discriminate between "informed" and "uninformed" customers. These incentive changes give pricematching policies the potential to raise prices above the competitive level, possibly even to the level that an unregulated monopoly would charge.

Price discrimination plays a central role in the anticompetitive power of price matching. If firms could not price-discriminate, they might not have an incentive to adopt price-matching policies in the first place. For example, consider the more traditional, though less realistic, assumption that all customers are fully informed of sellers' prices. If all firms are charging low, competitive prices, a pricematching seller that raises its price will not increase its profits, since all buyers will demand the competitive price. ${ }^{26}$

The traditional view of price-matching policies, as offered by Ayres, Clark, Salop, Sargent, and Simons, does not consider the likelihood that some buyers are uninformed and the resulting potential for price discrimination to drive prices upward. ${ }^{27}$ Such a view neglects the full power of price matching. Although it does demonstrate that price matching can help to sustain a cartel's price-fixing agreement by eliminating the profits usually gained from undercutting the agreed price, it does not explain how firms come to charge high prices without a collusive agreement and coordination. ${ }^{28}$ It also does not reveal the extent to which price-matching policies challenge traditional interpretations of the antitrust laws. Sargent comes closer to such an appreciation when he asks whether price-matching policies can be useful for forming agreements, instead of merely for maintaining them. In the end, however, he concludes that the sort of price-matching policies considered in this Article do not encourage firms to raise prices above competitive levels. ${ }^{29}$

Car, 85 AM. ECON. REv. 304, 309 (I995). The prices on many industrial supply purchases are similarly determined on an order-by-order basis and will vary among customers.

Despite the influence of additional factors, the argument for such markets is similar. A firm can charge higher prices, with less fear of losing those buyers that have received lower offers elsewhere, if the firm offers a matching policy.

26 If some customers were averse to having a price matched, as Hviid and Shaffer have argued, firms could in fact lose business by raising their prices. See Hviid \& Shaffer, supra note 24, at 3 ; infra section I.C.

27 See supra note 14 .

28 In a duopoly model such as the one offered by Belton, in which one firm can choose its price before the other, firms can easily coordinate to avoid pricing competitively. When there are many firms, however, coordination is difficult. See Belton, supra note 9 , at 403 .

29 Because Sargent does not consider price discrimination, he argues that the anticompetitive effects of price-matching policies are less pronounced than those of price-beating policies. See Sargent, supra note 14 , at $2075-78$. 
This Article argues that price-matching policies are much more powerful: once one considers a more realistic model in which some customers are poorly informed about the price each seller charges, an individual firm will have a significant incentive to raise prices to pricediscriminate. Consequently, these policies can lead to high prices without any agreement, spoken or unspoken, and even when many firms enter the market. Because cases arising under section I of the Sherman Act are predicated on collusion, this feature can make price matching difficult to attack. This Article argues, however, that a Sherman Act attack may still be possible, and moreover that the price discrimination between buyers based on either information or exclusive offers they possess ${ }^{30}$ may violate price-discrimination laws or unfair-competition laws. Ironically, the fact that price matching may have little to do with collusion not only makes it harder to attack, but also suggests that the policy problem posed by price matching is more substantial than that posed by cartels. High prices are inherently unstable when they are sustained only by a collusive agreement: high prices invite entry, and, as firms become too numerous, agreements become unworkable, whether they are tacit or explicit. ${ }^{31}$ Price matching, in contrast, can maintain high prices even when barriers to entry are low. It thus has the potential to upset competitive markets in more settings than the traditional targets of antitrust: cartels and monopolies. ${ }^{32}$

Moreover, high prices are costlier to society in markets with entry than in markets with just a few cartelized firms and no entry. When a cartel charges high prices, a good deal of what buyers lose is transferred to the coffers of the cartel..$^{33}$ In contrast, in a market with entry,

30 See supra note 25 (regarding exclusive offers).

31 In his classic article on oligopoly, George Stigler views as too obvious to require substantiation the fact that "collusion is impossible" in industries with a large number of firms. George J. Stigler, A Theory of Oligopoly, 72 J. PoL. ECON. 44, 44 (I964), reprinted in George J. Stigler, THE ORganization of INDUSTRy 39 (I968). See generally Richard A. POSNER, ANTITRUST Law: AN ECONOMIC PERSPECTIVE 39-77 (1976) (discussing the problems associated with maintaining a cartel and citing Stigler's proposition with approval); F.M. SCHERER \& DAvID Ross, INDUSTRIAL MARKeT STRUCtURE AND ECONOMIC PERFormance 235-76 (3d ed. I990) (discussing the difficulty of maintaining cartels and conditions that facilitate their formation).

32 In markets without price matching, cartels and monopoly power can generally be sustained only in the presence of some natural or government-imposed barrier to entry. Otherwise, new entrants tend to dissipate all supranormal profits. See generally DENNIS W. CARLTON \& JEFFREY M. PERLOFF, MODERN INDUSTRIAL ORGANIZATION 850-908 (2d ed. r994) (discussing potential inefficiencies of regulation). For example, Kleidon and Willig argue that a cartel is inherently implausible on NASDAQ, because the entry barriers to become a market maker for any given security are low. See Allen W. Kleidon \& Robert D. Willig, Why Do Christie and Shultz Infer Collusion From Their Data? 6 (Apr. 3, r995) (unpublished manuscript, on file with the Harvard Law School Library) ("When entry is easy, cooperative efforts by incumbents to maintain excessive prices simply attract entrants who undercut collusive prices and restore competitive outcomes.").

33 Wealth is also destroyed to the extent that higher prices discourage some purchases. See infra note 67 . Consumer surplus, which represents the benefit in dollars that buyers derive from a 
in which high prices are sustained by price matching, this transfer is lost, because the high prices invite many firms to incur the set-up costs required to enter the market. Firms continue to enter until demand becomes so fragmented that profits disappear, even at the high prices sustained by price-matching policies. ${ }^{34}$ The inefficient replication of fixed costs is pure waste: society has no more to show for the firms' high revenues than if the money were simply burned.35 These arguments about the welfare cost of price matching are described in more detail in section I.D. 36

\section{B. A Simple Model of Price Matching}

A simple model will illustrate the arguments presented above. ${ }^{37}$ The model reveals that high prices may result even when there is no collusion by sellers, spoken or unspoken, and even when many firms enter the industry. The key to this conclusion is that, when prices are low, price matchers have the incentive to raise prices in order to pricediscriminate and to take advantage of uninformed buyers.

Consider the market for changing oil in automobiles. Assume that all oil changers perform a similar service and have the same cost structure. Because there are significant fixed costs involved in setting up an efficient oil change service (for example, buying tools and building a drive-over pit), average costs will be high if the firm has few customers. $^{38}$ Assume that the lowest possible average cost is $\$$ I5 per oil

purchase, equals the area beneath the demand curve, but above the price. As the price rises above the cost, this area shrinks, and consumer welfare falls with it. Much of this fall is reflected by an increase in the rectangular area between price and cost, which is the cartel's or monopoly's profit. This area is not a social loss, but merely a transfer from the buyers to the cartel. The excess loss is the shaded triangle in the figure below in note 67 , which represents the "deadweight loss" associated with the price rise. To the extent that buyers buy less at higher prices, this triangle reflects pure waste: the value of each additional unit along the horizontal axis of this triangle exceeds its cost (because the demand curve is above the cost), and the failure to produce these units is thus wasteful. For small price increases, the area representing the transfer dwarfs the area representing wealth destruction. This disparity need not be the case for large price increases. For a discussion of deadweight losses in general, see CARLTON \& PERLOFF, cited above in note 32 , at $105-06$.

34 As long as profits remain, more firms will want to enter. See Kleidon \& Willig, supra note 32 , at 6 .

35 As section I.C explains, the loss from this scenario includes a "rectangle" from increased average costs, in addition to the usual triangle representing the deadweight loss from reduced output under monopoly.

36 See infra note 69.

37 The model is highly stylized and is not intended to convey a literal or perfect image of the world. Its purpose is to explain clearly the fundamental tendencies of price matching. In practice, many complications arise, some of which limit the force of these arguments. Section I.C, below, explores these complications and argues that the fundamental tendencies nonetheless survive.

38 Oil changers probably have U-shaped average cost curves, the standard assumption made in the industrial-organization literature. See CARITON \& PERLOFF, supra note 32, at 53. Under Ushaped average costs, average costs fall until the firm nears capacity, because the firm has more customers among whom to divide fixed costs. After optimal capacity, marginal costs begin to rise, which in turn causes average costs to rise as well. In some cases, such as an airplane flight, it is 
change, and that this cost is reached if rooo customers are served per month.

Assume that each customer is willing to pay $\$ 30$ for an oil change, but that she will change her oil herself if the price is higher. In this case, a monopoly would charge customers their full willingness to pay, \$30. In contrast, in a competitive market, two important forces drive the market toward the competitive price of $\$ I_{5}$ per oil change: price cutting and entry.

Price cutting is the first competitive force. If the market price exceeds the minimum average cost of $\$ \mathrm{r} 5$ and the oil changers are selling to fewer than the efficient production level of I000 customers, each oil changer will want to cut its price to attract customers. Provided that a small price cut by one firm will increase its demand substantially, ${ }^{39}$ its profits will rise, because the number of customers and the profit margin per customer will both increase as the firm comes closer to efficient scale and average costs fall toward $\$ 15$.

Entry is the second competitive force. If price exceeds $\$$ I5 and each oil changer serves rooo or more customers, each oil changer may be so busy that its incremental cost of serving an additional customer has risen to equal the high price. In this case, no firm will want to cut its price and increase its business. However, such a situation indicates that firms are making positive profits, which will attract entry.40 Entry will lower prices because entrants will tend to charge a lower price to gain market share and existing firms will also cut price in an effort to maintain market share. ${ }^{41}$

Some combination of price cutting and entry followed by price cutting will occur until sellers charge the competitive price of $\$$ I5 per oil change and enough oil changers have entered the market to supply all the customers. If there are roo,ooo customers per month and each oil

simply not possible to produce beyond capacity without a new plant: for example, once all the seats on a flight are filled, a second flight is necessary to serve additional passengers.

39 In a competitive market, a price cut by one firm steals a substantial amount of business from its rivals. This assumption is standard in competitive markets and follows in the example if an oil change from one firm is a good substitute for an oil change from another. In a perfectly competitive market, firms can attract any number of customers, up to the total market size, with an arbitrarily small price cut. Thus, when firms operate at a less-than-efficient scale and price exceeds the minimum of average cost, a firm can always increase profits by cutting price by a small amount.

40 To check this assertion, note that each firm could refuse to serve any customers beyond rooo and would then be making positive profits because price will exceed $\$ 15$, the average cost when Iooo customers are served.

41 The technical explanation for this response by incumbents is that, as firms sell less, their own demand elasticity rises. In a Cournot model, demand elasticity is given by $(p / q) s$, where $p$ is the market price, $q$ is the quantity the firm sells, and $s$ represents the sensitivity of market demand to price. Therefore, for any given market price, the firm's demand elasticity rises as $q$ falls. 
changer can efficiently sell to Iooo of them, a competitive equilibrium will have Ioo oil changers. ${ }^{42}$

If all customers are aware of all available prices, price-matching policies will not unsettle this competitive outcome. Under full information, adopting a price-matching policy will not increase a firm's patronage. Because customers know that all oil changers are still offering the same effective price, they will not want to switch from the oil changer most convenient to them. If the price matcher raises its price as well, all of its customers will demand the lower price, so the oil changer will receive no extra profits. Hence, in an idealized world of fully informed consumers, as long as firms do not coordinate their efforts, the competitive equilibrium of $\$$ I 5 remains even if oil changers have the option to adopt price-matching policies. In this setting, these policies do not create incentives to raise prices above competitive levels. ${ }^{43}$

The situation changes substantially in more realistic situations in which some consumers are uninformed. Consider modifying the above example so that some positive fraction of customers do not know the available prices. For the sake of concreteness, assume that ninety percent of customers are fully informed of available prices, and that ten percent are uninformed because they find price shopping prohibitively costly. ${ }^{44}$ Let $N$ represent the total number of oil changers, and let $N_{\text {low }}$ represent the number of oil changers either charging the lowest price

42 "Efficiently" in this case, means that firms are producing goods (here, oil changes) at the lowest possible average cost.

43 One might argue based on "weak dominance" that, even without coordination and even when all buyers are informed, price-matching policies lead to monopoly prices. See DrEw Fudenberg \& Jean Ttrole, Game TheORY 6-9 (I9gI) (formally discussing weak and strict dominance). The idea behind such an argument is that, in a competitive equilibrium, a firm would be better off in a "weak" sense by charging the monopoly price and having a pricematching policy than by charging the competitive price. Although these two strategies lead to the same profits if rivals charge the competitive price, as the equilibrium prescribes, if all rivals accidentally or mistakenly raise their prices, the firm will be better off with the high-price strategy. One difficulty with such an argument is that, if rivals make a different sort of mistake and charge a price below the competitive price, the firm will regret its matching policy. Such a "mistake" might be particularly plausible if there were some probability that rivals had lower costs. Ultimately, an argument for high prices has more force if there is a "strong" incentive to charge high prices than if there is a "weak" one.

44 The exact fraction is irrelevant for the price-matching equilibrium, but would affect a competitive equilibrium in the absence of price matching. If there were sufficiently few uninformed customers, all firms would charge the competitive price of $\$ 1_{5}$, and a firm that tried to skim off the few uninformed customers at a high price would be unable to cover its fixed costs and would lose money. If there were a higher proportion of uninformed customers, the equilibrium would involve two prices: some firms would charge $\$ 30$ and serve only uninformed customers, while others would charge $\$ 1_{5}$ and serve all customers. For an explication of the tendency toward bipolar prices within more complex mathematical models of price setting and consumer search, see Steven Salop \& Joseph Stiglitz, Bargains and Ripoffs: A Model of Monopolistically Competitive Price Dispersion, 44 REv. ECON. STUD. 493, 497-509 (1977), and Hal R. Varian, A Model of Sales, 70 AM. ECON. REv. 65I, 652-57 (I980). In contrast, with price matching, all firms will charge \$30. See Salop \& Stiglitz, supra, at 499-502. 
in the market, or posting a higher price but charging the informed customers the lowest price through a price-matching policy. The informed customers will split among these $N_{\text {low }}$ oil changers, because they have the lowest effective prices. For the sake of simplicity, assume the informed customers divide evenly among these firms. Assume also that the uninformed customers - the customers who find price comparison too costly - split evenly among all $N$ oil changers. ${ }^{45}$

Consider an oil changer that effectively charges the lowest price on the market. How many customers will it attract? Because the 90,000 informed customers will divide among the $N_{\text {low }}$ oil changers with the lowest effective price, this oil changer will get $90,000 / N_{\text {low }}$ of these customers. Because the 10,000 uninformed customers will divide among all $N$ firms, this firm will get 10,000/N of these customers.

What happens if a low-price oil changer raises its price? If it is not a price matcher, the oil changer will lose all of its informed customers. They will go to an oil changer charging a lower effective price, and the oil changer will be left with only 10,000/ $N$ customers. This lost patronage is what discourages price hikes in a healthy market: in the extreme case in which all customers are fully informed, no customers would remain after the price hike. ${ }^{46}$

However, a firm that adopts a price-matching pledge can profitably raise prices. As long as the oil changer does not try to charge more than customers are willing to pay (say, \$30), it will not lose patronage, and it will make more money from its uninformed customers through a form of price discrimination. This discrimination is a very important feature of price-matching policies. As long as the lowest-priced oil changers charge less than the monopoly price $(\$ 30)$, any one of them will profit from adopting a price-matching policy and raising its price.

Low-priced firms thus have an incentive to raise their prices until they all charge $\$ 30$. It is stable for all firms to charge $\$ 30$ if each firm promises to match prices. (Under more realistic search assumptions, the $\$ 30$ price may be stable even when only some firms match prices. ${ }^{47}$ After all, a firm that cuts prices can only attract customers from the non-price-matching firms. If all the firms match prices, then cutting prices will not be profitable. Price matching thus undermines the two natural incentives for low prices in healthy markets: the incentive to undercut rivals to get their business, and the disincentive to charge more than rivals for fear of losing customers.

45 Assuming that customers divide themselves evenly among firms with the same effective price ignores hassle costs and switching costs. See infra section I.C (discussing these costs).

46 If enough customers are informed, raising prices is unprofitable. Below this proportion of informed customers, the equilibrium without price matching would involve firms selling at two prices, some at \$15 and others at \$30. See Varian, supra note 44, at 653-55. With price matching, all firms would eventually charge $\$ 30$.

47 See infra Appendix section A. 
Of course, if firms in the market are making profits at the monopoly price, new firms will want to enter. Entry is usually thought to drive prices down because the entrant will undercut the prices that incumbents charge to attract business from them, and incumbents, in turn, will lower prices to recapture some sales. 48 When firms all have price-matching policies, however, incentives are different. Entrants will be unable to underprice incumbents because of incumbents' matching offers, so entrants will also charge \$30: instead of cutting prices to attract business, they will be forced to do so by advertising. Another way to see that entry will not drive prices down is to observe that the preceding arguments demonstrating that firms would charge $\$ 30$ make no reference to the number of firms in the market. 49

As new firms enter the market, existing firms will have fewer customers over whom to amortize their fixed costs, so firms' per-unit costs will rise. Firms will continue entering as long as price exceeds average costs. ${ }^{50}$ New firms will stop entering the market only when per-unit costs have risen to $\$ 30$. It then profits no new firm to enter the market, and no existing firm to change its pricing policy.

\section{Limitations of Price Matching}

The model in the previous section makes many simplifying assumptions. Although some are irrelevant to the conclusions, others are more important, and relaxing them will generally reduce the tendency of price matching to raise prices. This section will explore these issues and argue that price matching raises prices in most realistic settings, although probably not to monopoly levels.

The previous section presented a highly stylized model of demand. In the model, each customer had the same demand and would consume one oil change for prices up to some "reservation" price, and no oil changes for higher prices. The conclusions of this model would be unaffected if demand were to fall continuously as price rises or if demand were to vary among buyers, as the Appendix demonstrates. ${ }^{51}$

The model of the search process was also simplistic. In the model, customers were "born" informed or uninformed. In practice, customers must incur some cost to become informed (for example, reading newspaper advertisements or subscribing to a pricing service), and are more apt to do so when prices differ substantially among sellers than

48 See supra note $4 \mathrm{I}$.

49 In fact, Png and Hirshleifer show that, if firms match prices and customers with low search costs have more elastic demand than customers with high search costs, then prices will actually increase with the number of entrants. See Png \& Hirshleifer, supra note II, at 367, 37273; see also infra p. 544 \& n. 53 (discussing search costs).

50 Note that these average costs include returns to capital and entrepreneurship. Economic profits are returns in excess of these returns and should be driven to zero in this example, even though accounting profits, which appear in firms' financial statements, should not.

51 See Edlin \& Emch, supra note 6, at II-14; infra Appendix section B. 
when they are similar. Accounting for this observation, however, would leave our conclusions unaffected. In fact, Edlin and $\mathrm{Emch}^{52}$ arrived at the same conclusions as the model in the previous section in a model in which search costs vary among buyers and some buyers become only incompletely informed because they are willing to search only a few competitors. . $^{3}$

Another simplification of the model in the previous section was that, even though price discrimination was the dynamic that broke the competitive equilibrium, all firms ended up charging the monopoly price. In this simplified case, price-matching policies are latent: they are important because they support the equilibrium, but they are never actually used. In a more sophisticated model in which search costs and demand are statistically correlated, prices may vary among sellers, and some buyers may use price-matching policies in equilibrium, as Professors Hirshleifer and Png have demonstrated. ${ }^{54}$ In the Hirshleifer and Png model, informed and uninformed buyers have different demand curves, so that there are two relevant monopoly prices - the price that would be charged if all buyers had the demand of informed buyers, and the price that would be charged if all buyers had the demand of uninformed buyers. Prices vary among sellers in their model but always fall between these two monopoly prices.

Another reason that price will vary among sellers and that only some sellers should be expected to adopt price matching is that sellers often have different costs. When costs differ, the monopoly price for a low-cost seller will be lower than for a high-cost one. The low-cost seller will have no reason to raise its price above its own monopoly price, but the high-cost seller will typically charge a higher price. ${ }^{55}$ If

52 See Edlin \& Emch, supra note 6, at 5-6.

53 There are an enormous variety of ways to model search, and unfortunately there is no consensus among economists as to the best way. If Edlin and Emch had chosen a different model of search, their conclusions about price matching might have changed. For some search strategies that would be interesting to put in a price-matching model, see David M. Grether, Alan Schwartz \& Louis L. Wilde, Price, Quality and Timing of Moves in Markets with Incomplete Information: An Experimental Analysis, IO2 EcoN. J. 754, 754-55 (1992); David M. Grether, Alan Schwartz \& Louis L. Wilde, Uncertainty and Shopping Behaviour: An Experimental Analysis, 55 REV. ECON. STUD. 323, 324-26 (1988); and Louis L. Wilde \& Alan Schwartz, Equilibrium Comparison Shopping, 46 REv. ECON. STUD. 543, 543-44 (1979). Price matching may be an even more attractive strategy under the search technologies discussed by Wilde and Schwartz. See Wilde \& Schwartz, supra, at 544-5r. Shoppers are more likely to buy from a price matcher than even lower-priced non-matchers; they will tend to make their last stop at a price-matching store, because doing so would not sacrifice their ability to take advantage of any earlier low prices and may provide them with a low price if, by chance, the price matcher offers a low price. See Michael Rothschild, Searching for the Lowest Price When the Distribution of Prices Is Unknowm, 82 J. POL. ECON. 689,689 (1974) (showing that qualitative properties of optimal search strategies when the distribution of prices is unknown are often the same as when the distribution is assumed to be known).

54 See Png \& Hirshleifer, supra note II, at 370-7 I.

55 A firm raises price until reductions in demand, which eventually lower revenues, offset the lower costs of servicing fewer buyers. A high-cost firm has higher cost savings from output reductions than a low-cost firm and, for this reason, generally charges higher prices. See Aaron S. Ed- 
a seller has costs so high that it is unprofitable to sell at the price of low-cost firms, it will abandon its matching policy and specialize in selling to uninformed buyers. Thus, in practice, we should not necessarily expect every firm to post the same price, nor every firm to offer a matching policy. These observations also imply that, even if matching policies raise prices, firms with matching policies may nonetheless tend to post low prices because the policies tend to be adopted by lowcost firms. These low-cost firms would charge even lower prices without the policy.

The model in the previous section also assumes that buyers can costlessly take advantage of a price-matching offer. Professors Hviid and Shaffer have criticized this assumption by pointing out that if buyers incur a "hassle" cost in invoking the offer, then, even if all of a firm's rivals match prices, the firm will still have some incentive to undercut its high-priced rivals, because buyers may be unwilling to incur this hassle cost. ${ }^{56}$ Certainly, this argument has merit: hassle costs will reduce the power of price matching to raise prices. ${ }^{57}$ This argument, however, ignores an important countervailing factor: in addition to hassle costs, buyers often face substantial costs in switching sellers. That is, they become accustomed to a seller and develop a valuable relationship with it, whether business or personal, or may simply prefer buying from a more convenient location. ${ }^{58}$ To the extent that these switching costs exceed hassle costs, some buyers will prefer going to their favorite or regular supplier, and getting that supplier to match a lower price offered elsewhere, to going to the store with the lowest posted price. Sellers can and do encourage buyers to make use of price-matching policies instead of switching sellers by advertising low hassle costs and offering bonuses to compensate for hassle costs. ${ }^{59}$ As long as some buyers use the matching policy, the incen-

lin \& Chris Shannon, Strict Monotonicity in Comparative Statics, J. ECON. THEORY (forthcoming r998) (providing a mathematical formalization and generalization of this fact).

56 See Hviid \& Shaffer, supra note 24 , at 2.

57 In a perfectly symmetric model, hassle costs eliminate the anticompetitive power of price matching, though in the more realistic case of an asymmetric model, hassle costs arguably only reduce the power of matching. See $i d$. at 3 .

58 For each customer $i$ there is some cost $d_{i}$ of overcoming the distance to the second-most convenient store. Those for whom the hassle cost of getting a price matched is less than $d_{i}$ cannot be drawn away from a nearby price matcher. This captive demand implies that a price matcher will find it profitable to raise its price above what it would charge if it did not match. Customers' demand elasticity is lower because of the effectiveness of the firm's matching policy with these customers.

59 For example, Circuit City has run television advertisements showing that a small child is able to take advantage of a matching offer with a smiling salesperson in a matter of seconds. See Edlin \& Emch, supra note 6, at $6 \mathrm{n}$. 12. The Sports Authority emphasizes that their matching offer is "[h]assle free!". See The Sports Authority, supra note 2. Rasputin's Records in Berkeley, California, which accepts competitors' discount coupons, gives customers a free slice of pizza for taking advantage of its offer. See Edlin \& Emch, supra note 6, at $8 \mathrm{n}$. I5. Price-beating pledges can also be interpreted as compensation for hassle costs. As Edlin and Emch speculate: 
tive to undercut is weakened. Because of switching costs, as a matcher raises its price, it will keep some of the customers that it would lose without the matching policy. This effect gives the price matcher an incentive to charge higher prices than it would without the policy.

Another consideration that the model in the previous section leaves out is that buyers may simply believe that a matcher has low prices, regardless of whether it does in fact. Such a captive demand encourages price hikes. ${ }^{60}$ Still another complication is that sellers may try to charge low prices without advertising in the hope that, once customers come to the seller, they will not want to leave to go to a matcher. They could announce, as many firms do, that their prices are "too low to advertise." 61 If firms do not advertise, however, they are effectively raising customer search costs, and markets with high search costs generally suffer high prices. Thus, we cannot expect the refusal to quote prices to bring back low, competitive prices.

These arguments suggest that price-matching policies will raise prices to noncompetitive levels in most realistic settings, even though, unlike in the model of the previous section, prices may not rise to the same level that an unrestricted monopolist would charge. The fundamental noncompetitive forces identified in the previous section remain valid because a price matcher will lose fewer customers from a given price hike than will a seller that does not match, provided that the price-matching seller retains some informed or semi-informed buyers because of the matching offer (that is, provided that the switching cost exceeds the hassle cost for some buyers after taking into account any bonus that the seller offers). ${ }^{62}$ It follows that a firm will want to charge a higher price once it adopts a price-matching policy and that rivals will want to charge higher prices once a firm adopts a price-

Attempts at reducing transaction costs will likely become more common as commercial exchange moves increasingly into computer networks, such as the World Wide Web. Firms, for example, could send search agents [computer programs] crawling around the Web to check prices for a customer, and promise to charge the lowest price found or refund the difference of any lower price later found.

Id. Taking advantage of such an offer would cost the consumer nothing: in fact, it would reduce her search costs by making her own search superfluous. It is true that such policies eliminate price discrimination from price matching and may therefore lessen price matching's anticompetitive impact, because they eliminate the strong incentive of a matcher to raise its prices above that of rivals in order to discriminate. On the other hand, automatic matching will dramatically reduce rivals' hopes of gaining business by price cutting and thereby strengthen the other anticompetitive prong of price-matching policies.

60 Overall demand becomes less elastic and firms post higher prices if some buyers become less price sensitive because price matching lulls them into complacency.

61 See, e.g., The Traders, Advertisement, SAN JOSE MERCURY NEws, July 3, r994, at r3C (advertisement for gun store).

62 In the models presented above, a price hike does not repel any customers if the store raising prices is a price matcher. In practice, some customers may go elsewhere because of a price rise; however, fewer customers would leave a price matcher than a non-matcher. 
matching policy. These two tendencies interact with the standard tendency of one firm to raise its price when others do. This positive feedback suggests that final prices under price matching will be significantly higher than they would be without matching. ${ }^{63}$

A final consideration is that the model in the previous section assumes that all firms in the market sell a homogeneous product. Firms can differentiate their products as one way of cheating on a cartel: instead of chiseling on price, they may increase quality ("gold-plating"). ${ }^{64}$ This tendency may be significant under price matching, since quality matching is difficult to implement on a buyer-by-buyer basis. ${ }^{65}$ It will not necessarily lead to differentiation in equilibrium, however. Using a model of locational differentiation under price matching with two firms, John Zhang recently suggested that the two firms will differentiate their products only minimally. ${ }^{66}$ In a model of quality determination, all firms may raise quality to a very high level. This result may sound desirable, but quality comes at a cost, and it is wasteful to simulate a price cut in an unmatchable way by gold-plating products in circumstances where the value of gold-plating does not justify its cost.

\section{The Potential Social Cost of Price Matching}

Because price matching can keep prices high even in the face of entry, the introduction of price-matching policies to a market in which entry is possible can be much more socially costly than having a monopoly or cartel in a market in which entry is impossible. Customers may pay the same high prices in either case, but sellers get no benefits from the high prices with price matching if new firms enter until average cost has been driven up to equal the high price. The excess that customers pay over the competitive price is dissipated by the replication of fixed costs from overentry. This dissipation occurs even if fixed costs are extremely small: in this case, entry occurs until a huge number of firms are in the market, with the result that each firm's output

63 When a price rise by one firm leads other firms to raise prices, an industry is said to exhibit "strategic complementarities." See generally Jeremy Bulow, John D. Geanakoplos \& Paul D. Klemperer, Multimarket Oligopoly: Strategic Substitutes and Complements, 93 J. PoL. ECON. 488 , 488 (1985) (discussing games exhibiting strategic complementarities generally); Paul Milgrom \& John Roberts, Rationalizability, Leaming and Equilibrium in Games With Strategic Complementarities, 58 ECONOMETRICA I255, 1255 (I990) (same).

64 See CARLton \& PERLoff, supra note 32, at 188; Posner, supra note $3 \mathrm{r}$, at 60.

65 Executives of The Good Guys, a consumer electronics store, point out that it is no longer possible for them to compete on price with so many price matchers around, and thus the store must compete on other levels. See The Good Guys: Hidden Camera Spots Show Real World Sales People in Unreal Situations, Bus. WIRE, Aug. I2, x994, available in Westlaw, Bwireplus Database.

66 See Zhang, supra note 9, at 295-96. Zhang considers locational differentiation, the process by which firms "locate" their products relative to one another, but some of his intuition may also apply to other types of differentiation. 
is so small that, even with a small fixed cost, its average cost rises to equal the high price. In the simple example above, monopoly would not reduce aggregate social welfare, because demand is inelastic and a monopolist would choose to produce at the most efficient scale with costs of $\$ 55$, whereas the social cost of price-matching policies would be the extra \$15 in average costs for each of the 100,000 oil changes sold.

In a classical monopoly, the fact that customers pay a price in excess of the competitive price constitutes a transfer of wealth, not an inefficiency as such. The inefficiency that does arise is the "welfare triangle" lost because some consumers are willing to buy additional units at a price greater than the cost of producing these units, but cannot because the monopolist restricts output by pricing above cost. ${ }^{67}$ With price matching, however, the welfare loss is augmented by inefficient production: too many firms enter, each duplicating the fixed costs as

67 A classical monopolist raises prices above marginal cost. The situation is inefficient if this price increase causes the quantity purchased to fall. The size of the inefficiency equals the total excess of consumers' valuation over cost on each unit not purchased that would have been purchased if price equaled marginal cost. In our example, because the demand curve is perfectly vertical, this loss would actually be zero. If the demand curve is downward sloping, the deadweight loss equals the area of the triangular shaded region shown (Figure 1). See generally CARLTON \& PERLOFF, supra note 32, at 105-o7 (explaining welfare triangles, or "deadweight losses").

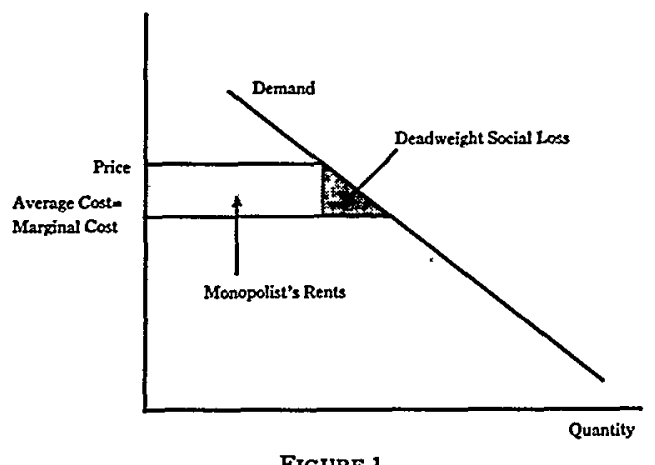

FIGURE 1 
sociated with doing business. ${ }^{68}$ This causes average costs to rise. Thus, price-matching policies may lead to a particularly pernicious form of monopoly pricing. Edlin and Emch have estimated that the extra welfare losses that could arise from replicated fixed costs under price matching could reach $\$ 5$ billion per year in the passenger airtravel market, and \$I9 billion per year in the wholesale gasoline market, if price matching became ubiquitous in these markets and the full anticompetitive potential of price matching were realized. ${ }^{69}$

68 When firms enter until average cost equals price, all the benefits that would accrue to a monopolist from higher prices are dissipated. The total inefficiency is represented by the shaded trapezoid below (Figure 2).

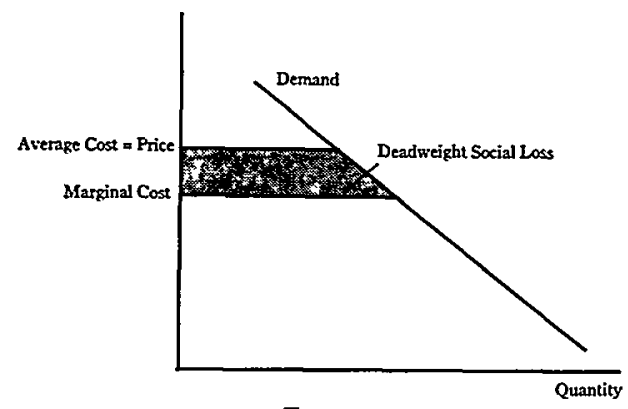

Figure 2

69 Edlin and Emch calculate the size of potential welfare losses from price matching and compare them with losses from ordinary price-fixing cartels and monopolies. The size of these losses depends on the demand elasticity and the ratio of fixed to marginal cost in a particular industry. See Edlin \& Emch, supra note 6, at I5-I9. Edlin and Emch estimate these effects in two specific industries: air travel and wholesale gasoline. See id. at 20-23. In each case, they use previously published estimates of the demand elasticity, along with an estimated ratio of fixed to marginal cost, based on public data. In both cases, total welfare losses would be approximately $\$ \mathrm{r} 2$ billion under monopoly or cartel, compared with total U.S. sales of approximately $\$ 70$ billion. At $\$ \mathbf{r} 6$ billion, price matching would yield somewhat higher losses than monopoly or cartel in the airtravel market. In contrast, losses under price matching would soar to $\$ 30$ billion in the wholesale gasoline market. See id. at $2 \mathrm{I}$.

Welfare losses relative to perfect competition have two potential sources: a higher price than under competition, and higher industrywide average costs than under competition. In Edlin and Emch's model, an industry is made up of many small firms, each with a production capacity of $Q$, fixed production cost of $F$, and marginal per-good production cost of $c$. See id. at 6-7. Given a demand elasticity and ratio of fixed to marginal cost in an industry, Edlin and Emch's model yields an equilibrium price and resulting average cost level under each of the three scenarios.

In their calculations of the potential losses from price matching, Edlin and Emch assume that entry is possible. The high prices from price matching attract entry, but entry does not drive down prices because of the matching policies. Rather, entry entails a replication of fixed costs, which drives up average costs and leads to the high potential losses that Edlin and Emch find in the wholesale gasoline and airline markets. For purposes of comparison, they also consider a more traditional cartel that keeps prices high by restricting entry instead of by adopting a pricematching policy. Although a cartel would have substantial welfare losses from high prices, Edlin and Emch find that such Iosses are substantially lower than when entry is possible and price matching keeps prices high. They also find that monopoly has much lower potential losses than 


\section{E. Differences Between Price Matching and Related Practices}

At this point, it is worthwhile to ask what a price-matching policy accomplishes that either simple threats to lower prices if others lower them, or two-party most-favored-customer clauses, do not.70 Both retaliatory threats and most-favored-customer clauses can lead to high prices, but neither is as anticompetitive as price matching because neither works simultaneously on the two fronts that price matching policies do: creating an enhanced incentive for the matching firm to raise prices and a diminished incentive for the matching firm's rivals to lower prices. ${ }^{71}$

There are two essential distinctions between matching prices and threatening to lower prices if others do. Both distinctions follow from the fact that a price-matching policy is customer-based: it is a promise to customers, rather than a threat to sellers. That is, if a given customer demands a match, then that customer, but not others, gets the low price. In contrast, under a "threat-based" matching policy, the seller lowers the price to all buyers whenever a rival does.

One distinction, therefore, is that a single seller shielded by a pricematching policy can unilaterally raise its price above the competitive level and increase profits by exploiting poorly informed customers. This capability is missing from threat-based matching, and consequently departures from competitive prices require coordination in a threat-based system: a price leader will price itself out of the market if other firms do not follow it. ${ }^{72}$ Because coordination is often difficult, price-matching policies provide a much simpler route to achieving high profits.

Issues of cost and credibility form the second distinction between promises to buyers and related threats to sellers. Promises to buyers are a less costly way of discouraging other firms from lowering their prices. The cost of monitoring falls because customers themselves will notify a price-matching seller if another seller lowers its price on some good. In contrast, a seller wanting to make good on a threat to lower prices whenever rivals do must keep track of all the prices of all of its

price matching in the two industries they consider, because, although its price is high, a monopolist has a strong incentive to keep average cost low.

70 Most-favored-customer clauses, sometimes called most-favored-nation clauses, have appeared in several cases. See, e.g., Blue Cross \& Blue Shield United v. Marshfield Clinic, 65 F.3d I406, I4I5 (7th Cir. 1996); E.I. du Pont de Nemours \& Co. v. FTC, 729 F.2d 128, I34 (2d Cir. I984); United States v. General Elec. Co., 42 Fed. Reg. I7,004 (E.D. Pa. I977); United States v. Eli Lilly \& Co., r959 Trade Cas. (CCH) II 69,536 (D.N.J. r959).

71 See supra sections I.A, I.C.

$72 \mathrm{It}$ is possible for threats also to force firms to raise prices following a price hike, but these threats probably require explicit communication for coordination. Each firm will follow a price leader if it believes both that others will as well and that failure to do so will cause all firms to revert quickly to competitive prices. See POSNER, supra note 3r, at 45-47 (critiquing price leadership). 
rivals. ${ }^{73}$ In addition, the cost of meeting lower prices is smaller if those prices are only met for select customers. Price-matching policies target the customers at risk of buying elsewhere: namely, those that know of rivals' offering lower prices or that have received an "exclusive" offer at a low price. Low prices are not "wasted" on the uninformed.

Because lowering prices for all customers is costly, threatening to lower them is often not credible. If one firm lowers its price in the hope of gaining patronage, others might not follow immediately, because they want to continue to profit from uninformed customers. Competition works if three conditions are met. First, an initial pricecutter must realize short-run gains because other firms do not immediately follow it down the price ladder. Second, other firms must eventually cut their prices, once enough customers switch to low-priced firms. Third, the short-run gains to a firm that cuts its price must exceed the discounted long-run losses that the firm will suffer once others follow its price cut. The problem with price-matching policies is that the initial short-run gains that lure the first price-cutter may become too small to satisfy the last condition: in the model in the previous section, in fact, no short-run gains exist at all.

One may well ask how price competition can ever work if it is predicated on meeting these three conditions. The first and third conditions seem to contradict one another: why would other firms delay following a price cut if the third condition holds, so that the short-run gains from a price reduction exceed the long-run losses that will eventually be suffered when other firms also reduce prices? The reason other firms might delay is that a fundamental asymmetry exists between the first price cutter and the second. The short-run gains to the second price cutter are half as large as the gains to the first because the second price cutter must split the extra patronage of informed buyers with the first. A similar asymmetry exists between the second and third price cutters. Competition requires a delicate balance: the rate at which buyers must switch to a lower-priced firm must be fast enough to provide short-term gains, but not fast enough to force competitors to match the price cut and thus eliminate the short-term gains. Committing to an offer-based price-matching policy may render switching by buyers too slow for competition to work. On the other hand, simply threatening to match the general price reductions of other firms may not be credible because the fact that patronage gains justify the first

73 This information-gathering feature of price matching is reminiscent of the line of cases holding that agreements among sellers to exchange price information can violate section $I$ of the Sherman Act if such agreements tend to suppress price competition. See United States v. Container Corp. of Am., 393 U.S. 333, 337 (I969); American Column \& Lumber Co. v. United States, 257 U.S. 377,4 IO-I2 (I92I). 
firm's decision to reduce prices does not imply that others will profit from following quickly.

Consider now a second related practice: most-favored-customer clauses in long-term contracts. ${ }^{74}$ The differences between these clauses and price-matching provisions are substantial. A most-favoredcustomer clause commonly involves a seller promising a buyer the benefits of any price reduction the seller grants to any other buyer. ${ }^{75}$ In contrast, the price matcher meets the lowest price offered by other sellers.

The two policies have different economic effects. A firm that advertises a price-matching policy discourages rival sellers from lowering prices because it ensures that lower prices will be matched. In contrast, most-favored-customer clauses discourage the seller itself from lowering prices, because it would have to lower prices to many past customers. Rivals of firms that have such policies may be tempted to lower prices, because they have a diminished fear of being matched and so can dramatically increase market share. ${ }^{76}$

In addition to this economic distinction, there is an important legal distinction between most-favored-customer clauses and price-matching policies. Because most-favored-customer clauses involve a promise to sell to different customers at the same price, they comply with pricediscrimination laws. ${ }^{77}$ Price-matching policies, however, may give a different price to each customer. Thus, price discrimination plays an important role in distinguishing these practices, just as it did in distinguishing price matching from simple threats to lower prices if others do. Part III considers some of the legal issues raised by price discrimination. In the next Part, however, this Article explores how price matching should be treated under section $\mathrm{I}$ of the Sherman Act.

\footnotetext{
74 For economic analyses of most-favored-customer clauses, see Thomas E. Cooper, MostFavored-Customer Pricing and Tacit Collusion, I7 RAND J. EcoN. 377, 377 (I986); Charles A. Holt \& David T. Scheffman, Facilitating Practices: The Effects of Advance Notice and Best-Price Policies, I8 RAND J. ECON. I87, I93 (I987); and William S. Neilson \& Harold Winter, Unilateral Most-Favored-Customer Pricing: A Comparison with Stackelberg, 38 ECON. LETTERS 229, 229 (I992). For a legal analysis, see Clark, cited above in note 14 , at 932-34.

75 In practice, most-favored-customer clauses are sometimes used with price-matching clauses. Fry's Electronics, for example, in addition to promising to match other sellers' prices, guaranteed to refund the difference in price to customers who found a lower price than at Fry's within 30 days of their purchase (I5 days for microprocessors and memory). See Fry's Electronics, Advertisement, SAN JOSE MERCURx NEwS, July 3, I994, at 3A. Such a practice was at issue in du Pont, in which the court vacated an FTC order enjoining the practice. See E.I. du Pont de Nemours \& Co. v. FTC, 729 F.2d 128, I38 (2d Cir. 1984). But cf. United States v. Delta Dental, No. CIV.A.96-I I3P, I997 WL 527669, at *2 (D.R.I. March 4, I997) (entering a consent decree enjoining the defendant from using most-favored-customer clauses); United States v. Delta Dental, 943 F. Supp. I72, I73 (D.R.I. I996) (denying defendant's motion to dismiss complaint in same case).

${ }^{76}$ But cf. Cooper, supra note 74 , at $384-85$ (describing circumstances in which this reasoning might fail).

77 See du Pont, 729 F.2d at I34; see also 6 AREEDA, supra note I5, II 1435e, at 229-3I (discussing price protection or most-favored-buyer clauses).
} 


\section{Price Matching Under the Sherman Act}

In Part I, this Article argued that price matching has the potential to lead to noncompetitive prices and even to impose greater social costs than ordinary monopolies or cartels. ${ }^{78}$ Section I of the Sherman Act does not condemn all anticompetitive practices, however. ${ }^{79}$ Even when the combined effect of two or more firms' actions is to "restrain trade," these firms do not necessarily form a "combination" in restraint of trade, as banned by section $\mathrm{I}$. Firms only violate section $\mathrm{r}$, as it has been interpreted, if they have agreed to act in restraint of trade. ${ }^{80}$ Finding an agreement is therefore critical to any section I inquiry, and there has been a great deal of controversy over the years about what constitutes an agreement and when courts can infer one. Section II.A explores whether price matchers enter into a horizontal agreement with each other for purposes of section I analysis. Section II.B then asks whether a vertical agreement exists between a buyer and price matcher that could violate section $\mathbf{I}$.

\section{A. Horizontal Agreement}

Are firms that charge high prices and make price-matching offers conspiring in violation of section I of the Sherman Act? In some cases, they may be, and if there is direct evidence of sellers agreeing to charge high prices, courts will hold them to be in per se violation of the Act. ${ }^{81}$ This section argues, however, that courts cannot reasonably

\footnotetext{
78 Because entry may dissipate the profits from high prices, it is unnecessary to engage in the longstanding debate between populists and economists about whether profits should be counted in the social calculus. Populists generally condemn monopolies because high prices burden consumers, whereas economists condemn monopolies because, when price exceeds cost, many buyers who would willingly pay the cost of a product do not purchase it. Economists are generally not interested in the burden of high prices on consumers who nonetheless continue to purchase a product in the same quantity, because, although these consumers are injured by the high price, the seller typically profits to an equal extent. Thus the debate between the Chicago School and the more traditional school of antitrust can be reduced to a debate over whether the social calculus should count corporate profits and consumer wealth equally. See, e.g., Hovenkamp, supra note I4, at 244-49.

79 Section I bans every contract, combination, or conspiracy "in restraint of trade or commerce." I5 U.S.C. \$ I (I994).

80 The Supreme Court clearly articulated this principle in Copperweld Corp. v. Independence Tube Corp., 467 U.S. 752 (I984):

The Sherman Act contains a basic distinction between independent and concerted action.

The conduct of a single firm is governed by $\S 2$ alone and is unlawful only when it threatens actual monopolization ....

Section I of the Sherman Act, in contrast, reaches unreasonable restraints of trade effected by a contract, combination or conspiracy between separate entities. It does not reach conduct that is wholly unilateral.

Id. at 767-68 (citations and internal quotation marks omitted). In Monsanto v. Spray-Rite Service Corp., 465 U.S. 752 ( 1984 ), the Court emphasized that "[i]ndependent action is not proscribed" by section I. Id. at $76 \mathrm{I}$. The Court also noted that the plaintiff must present evidence "that tends to exclude the possibility" that the alleged conspirators acted independently. Id. at 764 .

81 See United States v. Socony-Vacuum Oil Co., 3Io U.S. I50, 2 I8 (I940).
} 
infer agreement from even the uniform adoption of price matching, because it is often in a firm's unilateral self-interest to adopt a matching policy.

The paradigmatic section I violation involves a group of sellers forming a cartel and agreeing to fix prices. ${ }^{82}$ Of course, firms may simply have an implicit understanding to refrain from price competition, or they may enter into an explicit agreement whose existence is impossible to prove directly. The courts have therefore struggled to determine when parallel pricing and other behavior allow or compel the inference of a price-fixing agreement. ${ }^{83}$ Under current doctrine, courts will not find a group of firms guilty of an antitrust violation just because these firms price in parallel, even when each firm's price affects the profitability of the other firms, so that price coordination is

82 See id.; United States v. Trenton Potteries Co., 273 U.S. 392, 396-98 (1927); United States v. Addyston Pipe \& Steel Co., 85 F. 27 I, 29I-92 (6th Cir. 1898), aff'd, I 75 U.S. 2 II (I899).

83 In Interstate Circuit, Inc. v. United States, 306 U.S. 208 (I939), the Court wrote in dicta that, although an agreement among film distributors to fix prices existed, such an agreement "was not a prerequisite to an unlawful conspiracy. It was enough that, knowing that concerted action was contemplated and invited, the distributors gave their adherence to the scheme and participated in it." Id. at 226. In American Tobacco Co. v. United States, 328 U.S. 78I (1946), the Court wrote that concerted action could include a situation in which "conspirators had a unity of purpose or a common design and understanding." Id. at 8ro. This seemed, for a time, to expand the bounds of section I beyond naked price-fixing agreements. Yet in Theater Enterprises v. Paramount Film Distributing Corp., 346 U.S. 537 (I954), the Court retreated, noting that "this Court has never held that proof of parallel business behavior conclusively establishes agreement or, phrased differently, that such behavior itself constitutes a Sherman Act offense." Id. at 541; accord United States v. General Motors Corp., r974-2 Trade Cas. (CCH) II 75,253, at 97,662 (E.D. Mich. I974) ("In the absence of agreement, there is nothing unlawful or improper in a businessman's raising his prices in the hope that his action will encourage his competitors to go further or for the purpose of testing the marketplace to determine whether further unilateral action is possible.").

Section 5 of the FTC Act might allow more leeway in finding an unlawful horizontal agreement, see 6 AREEDA, supra note I5, II I436c, at 243-45, but the Commission's previous attempts to expand section 5 much beyond section I of the Sherman Act have been frustrated, see E.I. du Pont de Nemours \& Co. v. FTC, 729 F.2d 128, r30 (2d Cir. 1984) (setting aside FTC ruling in In re Ethyl Corp., ror F.T.C. 425 (1983)).

The FTC's attacks under section 5 on industrywide base-point pricing systems illustrate the difficulty in equating identical pricing policies with illegal horizontal collusion. Base-point pricing is a convention in which the final delivered price paid by a customer equals the sum of the price of the finished good at the point of production and a shipping cost from some "base point," not necessarily the point of origin. When the base point is not the point of origin, this pricing convention ordinarily makes little sense. But it could, for example, be a unilateral profitmaximizing strategy in a model with an interstate dominant firm and a number of local fringe firms, for fringe firms to match the dominant firm's price by adding phantom freight from the dominant firm's point of origin. Nonetheless, the lack of a clear economic rationale for base-point pricing invites suspicion, and some economists have concluded that this type of pricing scheme exists only to facilitate collusion or price discrimination. See CARLTON \& PERLOFF, supra note 32, at 418. Courts have not, however, accepted industrywide base-point pricing alone as illegal: plus factors are required. See In re Plywood Antitrust Litig., 655 F.2d 627, 634 (5th Cir. 198I) (noting that a parallel pricing scheme, combined with direct evidence of communication between high-level personnel concerning pricing, provided sufficient evidence for a conspiracy under section $\mathrm{r}$ ). 
helpful. "Plus factors" must be present for a violation of section $\mathrm{I}$ : in other words, some independent circumstantial evidence indicating agreement must be introduced beyond mere parallel action. ${ }^{84}$

A court would probably not find the widespread adoption of pricematching policies to be such a plus factor. Although one can argue that most-favored-customer clauses, which section I.E compares to price matching, are a plus factor, the argument for price matching is not very convincing. Most-favored-customer clauses deter the adopting firm from cutting its own prices, because the cut would require refunds to previous customers, but may encourage price cuts by competitors that do not offer such clauses, because the most-favored-customer clause makes a response more costly. ${ }^{85}$ If adopting a most-favoredcustomer clause is unprofitable when other firms have no similar restriction, it might be reasonable to infer an agreement when most firms in an industry adopt these clauses.86 In contrast, the analysis from Part I suggests that a firm typically wants to adopt price matching on its own even if others do not adopt such policies. Hence, even the uniform adoption of price matching does not indicate that firms have formed an agreement, and would probably not cause a court to infer that sellers have agreed to fix prices. ${ }^{87}$

\section{B. Vertical Agreement}

This section considers the vertical relationship between buyer and seller and inquires into whether a seller that matches a price for a buyer might be entering into a contract or combination in restraint of trade and thus violating section I of the Sherman Act. A price-

\footnotetext{
84 At this point, parallel pricing can be used as evidence of a horizontal agreement, but a finding of an unlawful conspiracy depends on the presence of additional plus factors from which a court can infer agreement even if no conspiratorial smoking gun is found. These plus factors include circumstantial evidence of an express agreement, see Overseas Motors, Inc. v. Import Motors Ltd., 375 F. Supp. 499, 53 I (E.D. Mich. I974), proof that a motive to act in concert exists and that the offending behavior would not be in any firm's individual self-interest, see Venzie Corp. v. U.S. Mineral Prods. Co., 52I F.2d I309, I3I4 (3d Cir. 1975), or poor economic performance of the industry, as measured by high profits, see American Tobacco, 328 U.S. at 805-06; Estate of LeBaron v. Rohm \& Haas Co., 44I F.2d 575, 578 (gth Cir. I97I); AREEDA \& KAPLOW, supra note I7, at $312-13$.

Finally, in some cases, courts have inferred agreements from the completely free exchange of price information. See United States v. U.S. Gypsum Co., 438 U.S. 422, 434-35 (I978); Morton Salt Co. v. United States, 235 F.2d 573, 577 (Ioth Cir. 1956). However, courts have not found exchange of information through customers illegal.

85 See supra section I.E.

86 The FTC's inference of an agreement seemed particularly compelling with the mostfavored-customer clauses that RxCare imposed on pharmacists in Tennessee, because RxCare is itself owned by the largest pharmacists' organization in Tennessee. See RxCare of Tenn., Inc, 62 Fed. Reg. 4769 (F.T.C. I997); Baker, supra note I6, at 52 I-22.

87 "The absence of action contrary to one's economic interests renders consciously parallel business behavior meaningless, and in no way indicates agreement." Venzie, 52I F.2d at I3I4 (internal quotation marks omitted).
} 
matching seller offers to sell to a buyer at either the posted price $p$ or at any lower price $p$ ' that the buyer finds elsewhere. A buyer accepts the matching offer when it comes to the seller with an advertisement or other evidence of $p^{\prime}$ and buys at price $p^{\prime}$.

This section concludes that this contract is a restraint of trade and probably violates section I of the Sherman Act. It begins by drawing an analogy with other vertical arrangements between a buyer and seller that courts have found to be illegal because of their suspected impact on horizontal competition among either buyers or sellers. It then proceeds to examine two objections to this legal theory, the first focusing on intent and the second on causation.

It may initially seem odd to complain that sellers are charging high prices and then to point to a vertical agreement between buyer and seller as the culprit. However, antitrust doctrine does not require that a horizontal agreement be the cause of an injury to horizontal competition. Tying sales, refusals to deal with price cutters, exclusive-dealing arrangements, resale price-maintenance agreements, and territorial restrictions - all agreements between buyers and sellers - have been held illegal under section I when they are deemed to reduce competition among either buyers or sellers. ${ }^{88}$ In recent decades, the Chicago School has argued that these vertical agreements do not generally adversely impact horizontal competition. However, it has not questioned that such agreements are illegal when they do interfere with competition. 89

The real question, then, is whether the cause of decreased competition is the sale agreements between buyers and sellers or the unilateral offers by sellers to match prices. This Article suggests a straightforward answer. The matching policy of a seller can have no effect by itself. If no buyer took advantage of a price-matching offer, rivals would not have a diminished incentive to undercut a matcher. Likewise, the price matcher would not have the enhanced incentive to raise price and price-discriminate in the manner this Article describes. It is the joint actions of buyer and seller that change the competitive dynamic and lead to high prices. The buyer and seller, in combination and in contract, cause the injury. If the law prevents the buyer from invoking a matching policy and encourages it to buy at firms posting the lowest prices, then competition will work just as it does under the traditional economic theory described in Part I.

88 See cases cited supra note 16.

89 See William F. Baxter \& Daniel P. Kessler, Toward a Consistent Theory of the Welfare Analysis of Agreements, 47 STAN. L. REV. 615, 617-18 (I995) (arguing that the horizontal-vertical distinction has little meaning and that agreements should instead be classified as involving substitutes or complements); Frank Easterbrook, Vertical Arrangements and the Rule of Reason, 53 ANTITRUST L.J. I35, I35 (1984); Herbert Hovenkamp, Vertical Restrictions and Monopoly Power, 64 B.U. L. REV. 52I, 522 (I 984$)$. 
There are a variety of possible objections to the theory that the buyer and price-matching seller are engaging in an agreement that violates section $I$. First, the buyer is probably not intending to restrain trade. Rather, it is simply trying to get the lowest available price from the most convenient supplier. What could be wrong with that? Of course, a cartel's members are simply trying to get the best possible price for their wares, as sellers always do. 90 Any objection to their behavior should not be based on revulsion at their attempt to better their position: instead, it should be based on the consequences of this self-interested behavior for buyers.

The Sherman Act condemns a cartel's agreement because its consequences are to raise price above the competitive level and to restrict supply. In the oft-quoted words of Justice Brandeis, intent is important "not because a good intention will save an otherwise objectionable regulation or the reverse; but because [it] may help the court to interpret facts and predict consequences." 91 The "true test of legality" is whether competition is promoted or suppressed.92

Tie-jn sales provide one example in which intent has not governed. For instance, in International Salt Co. v. United States, ${ }^{33}$ buyers who purchased International Salt's Saltomat machine had to sign a contract promising not to use other sellers' salt in these machines.94 In cases like International Salt, the Supreme Court has concluded that the buyer is being forced to buy the tied product, such as salt, and objected because other sellers were foreclosed from the market. Although the buyer did not seek this foreclosure, it is still party to an illegal contract in restraint of trade violating section $1 .{ }^{95}$ The tie-in example does not prove, however, that intent is irrelevant on both sides of the transaction. After all, under the traditional view, the seller in a tie-in case is trying to foreclose others from entering a market. The seller's intent, however, does not distinguish a tie-in case from a price-matching case. A price matcher is trying to foreclose others from being able to compete on price. If competitors' products are suffi-

90 Many readers, particularly American ones, may find collusion of any sort offensive because they are so accustomed to thinking of those who join cartels or make predatory threats against other firms as criminals. My students from countries that lack antitrust laws or enforcement are often shocked by how American antitrust law imposes on the freedom of entrepreneurs who are simply struggling to make an honest living and not stealing or dealing in contraband!

91 Chicago Bd. of Trade v. United States, 246 U.S. 23I, 238 (I9I8).

92 This "rule of reason" was coined in Standard Oil Co. v. United States, 22 I U.S. I (I9II). See id. at 60. See generally AREEDA \& KAPLOW, supra note $I 7$, at I88-225 (discussing the development of the rule of reason and the per se illegality of price fixing).

93332 U.S. 392 (1947).

94 See id. at 394-95 n.5.

95 Despite the fact that section I clearly indicates that the buyer is a felon if he is party to such an illegal contract, the Justice Department has not generally pursued criminal charges against such a buyer. 
ciently similar to one another, ${ }^{96}$ and if monitoring the use of the product is costly, price matching can foreclose competitors even more effectively than a tie-in contract could. ${ }^{97}$

Another objection to the theory advanced here is that all a price matcher does is agree to sell to a buyer at some price. One can distinguish, however, a price-matching sale at a price $p$ from an ordinary sale at the same price. If other buyers must pay more than $p$, and if this buyer could only purchase at $p$ because it knew of another seller selling at $p$, the sale is a price-matching sale. If the seller systematically matches prices, and particularly if this policy is widely known, such agreements have the potential to injure competition. Of course, matching prices for a solitary buyer will generally have little effect. Nonetheless, the combined effect when matching is available to all buyers is significant.

In conclusion, price-matching offers can be quite anticompetitive, but they become harmless if the antitrust laws prohibit actually following through on an offer to match a price. For this reason, it is appropriate to pin antitrust liability on the matching sale transaction between seller and buyer.

\section{Does Price Matching Constitute Illegal Price DISCRIMINATION?}

Several state and federal price-discrimination and unfaircompetition laws prohibit price discrimination when the discrimination reduces, or has the potential to reduce, competition. ${ }^{98}$ These laws are not highly regarded, however. ${ }^{99}$ Critics argue that instead of protecting competition, these laws more often protect competitors, and par-

96 If products vary appreciably in quality, a seller with a superior product is foreclosed from luring its competitors' customers if those customers have entered into exclusive-dealing contracts, but the same seller could lure such customers away if the only tactic competitors used was price matching. However, if matching offers included a price increment for quality differences, as Anderson suggests, this caveat might be unnecessary. See Robert M. Anderson, Quick-Response Equilibrium 24-26 (1985) (unpublished manuscript, on file with the Harvard Law School Library).

97 With a tie-in contract, seller $A$ is foreclosed from selling to buyers that have signed a tie-in or other exclusive dealing contract with seller $B$ only to the extent that seller $B$ is able to monitor the purchases of those buyers. This monitoring is potentially quite problematic.

98 See supra note 17 .

99 The increasing disfavor of the Robinson-Patman Act is revealed by the steady decline in the number of complaints pursued by the FTC: an average of 74 per year in $1960-65$, six per year in I966-70, and more recently, only one in the whole period 1983-86. See Richard A. Whiting, R-P: May It Rest in Peace, 3I ANTITRust Bull. 709, 7II (I986); cf. CARLTON \& PERLOFF, supra note 32, at 840 ("One consequence of the Robinson-Patman Act is higher prices to consumers."); Thomas W. Ross, Winners and Losers Under the Robinson-Patman Act, 27 J.L. \& ECON. 243, 244 (I984) ("Robinson-Patman is no toothless tiger. ... [F]irms suffer large losses when actions are brought ...."). 
ticularly inefficient competitors. ${ }^{100}$ Additionally, these laws can actually promote price fixing by discouraging firms from offering secret price discounts that would undermine cartels. ${ }^{101}$ Price-discrimination laws may prove useful, however, in regulating price-matching policies. If these laws are interpreted to ban the price discrimination that is implicit in price matching, for once they will enhance competition instead of diminishing it.

Two federal statutes, the Federal Trade Commission (FTC) Act and the Robinson-Patman Act, could be used to attack the pricediscriminatory aspects of price matching. Such an attack would typically be easier under section 5 of the FTC Act than under the Robinson-Patman Act, because the substantive ${ }^{102}$ and jurisdictional ${ }^{103}$

100 See Marius Schwartz, The Perverse Effects of the Robinson-Patman Act, 3I ANTITRUST Bull. 733, 743-47 (I986).

101 See id. at $74 \mathrm{I}-43$.

102 One substantive issue that courts have not yet addressed is whether price matching involves price discrimination. On the one hand, buyers pay different prices depending on whether they know of lower prices elsewhere. In Anheuser Busch v. FTC, 363 U.S. 536 (I959), the Supreme Court held that discrimination under Robinson-Patman means simply the offering of different prices. See id. at 549. On the other hand, customers are all offered the same deal by price matchers in the sense that anyone who possesses a better offer gets the better price. An analogous circumstance arises in the case of quantity discounts, which are not discriminatory unless, despite being equally available to all, they are not "functionally" available to all. See FTC v. Morton Salt Co., 334 U.S. 37,42 (I948). Courts should apply this functional-availability doctrine when a manufacturer or other seller offers price matches, and hence a lower price, only to those customers lucky enough to have been quoted lower prices by competitors. (In the sale of new cars and many inputs, both discriminatory offers and price matching are common.) It is less clear that the offers are discriminatory if any purchaser can get lower prices by pursuing the same search. Still, if it is prohibitively costly for some buyers to pursue the search, they have a colorable claim of being discriminated against. It would have been possible for most or all buyers involved in Morton Salt to have bought a carload of salt themselves or as a group. They did not do so because, despite the carload discount, it was uneconomical. Individually, they did not need that much salt, and organizing to buy a carload as a group would have been costly. Similarly, a busy consumer may find it uneconomical to engage in an expensive, costly search for a low price. To summarize, the existing case law leaves unclear exactly what types of practices entail price discrimination under the Robinson-Patman Act. Although this Article argues that price matching sometimes involves price discrimination, the courts have not yet decided when it does. Section 5 of the FTC Act probably allows for a broader definition of price discrimination, but courts have never squarely decided the extent to which section 5 bans practices that are not prohibited by the Sherman or Clayton Acts.

103 For example, a typical retailer could not violate the Robinson-Patman Act, because the Act is confined to "in commerce" jurisdiction, but could violate section 5 of the FTC Act, because section 5 covers acts "in or affecting commerce." I5 U.S.C. \$ 45(a) (I994). Under "in commerce" jurisdiction, a sale across a state line is generally required. See Gulf Oil Corp. v. Copp Paving Co., 4I9 U.S. 186, 200-OI (1974); see also Robert M. Klein, The Robinson-Patman Act: Jurisdictional Aspects and Elements, 59 ANTITRUST L.J. 777, 778-82 (r9gr) (discussing the scope of the "in commerce" requirement). Recently, however, one district court found otherwise: "So long as its character and ownership remain constant, so long as it is not warehoused or otherwise stored for a substantial period, a commodity transported across state boundaries for subsequent sale remains in the flow of commerce [and] falls within the jurisdictional limits of the Robinson-Patman Act." Rio Vista Oil, Ltd. v. Southland Corp., 667 F. Supp. 757, 766 (D. Utah I987).

In any case, Areeda and Kaplow point out that the FTC " is no longer confined to in commerce jurisdiction even when it applies the substantive standards developed under the Clayton and 
scopes of the prohibitions of section 5 are broader. Even under section 5 , however, an attack on price matching would be difficult. Instead of attempting to consider all of a price matcher's possible defenses, this Part addresses only the assertion that it cannot be illegal to offer a discriminatory discount in an effort to retain a buyer that has received an equally low offer elsewhere.

A "meeting-competition" defense is included explicitly in both the Robinson-Patman Act ${ }^{104}$ and many of the state price-discrimination statutes. ${ }^{105}$ Other statutes, such as section 5 of the FTC Act, provide no explicit defense: even under these statutes, however, a price matcher could argue that meeting a competitor's equally low price is sufficiently procompetitive that the defense must be implicitly included in any prohibition of anticompetitive price discrimination. ${ }^{106}$ After all, such an act seems inherently competitive, and it would be paradoxical if the antitrust laws, whose purpose is to promote competition, were to ban procompetitive acts.

\section{A. The Meeting-Competition Defense}

Standard Oil Co. v. FTC is the leading case on the meetingcompetition defense. ${ }^{107}$ Standard Oil is generally read to establish the defense as a complete or absolute defense to a charge of violating section 2(a) of Robinson-Patman, ${ }^{108}$ but this Article will contend that such

Robinson-Patman Acts." AREEDA \& KAPLOw, supra note I7, at I53. Since I975, when the FTC Act was amended, anything "affecting commerce" has been covered by section 5 of the FTC Act. I5 U.S.C. $\$ 45$ (a) (I994). Under the "affecting commerce" jurisdiction, most retail price matching is probably covered by section 5 of the FTC Act, because most retailers buy goods for resale, or inputs, either directly or indirectly through interstate commerce. Therefore, if price matching raises prices and thereby causes output to fall, price matching affects interstate commerce via the retailers' purchases. "[T]he vital thing is the effect on commerce, not the precise point at which the restraint occurs." Mandeville Island Farms, Inc. v. American Crystal Sugar Co., 334 U.S. 2 I9, 238 (1948).

104 Section 2(b) of the Clayton Act, as amended by the Robinson-Patman Act, reads in pertinent part as follows:

Upon proof being made ... that there has been discrimination in price . . . the burden of rebutting the prima-facie case thus made by showing justification shall be upon the person charged with a violation of this section, and unless justification shall be affirmatively shown, the Commission is authorized to issue an order terminating the discrimination: Provided, however, That [sic] nothing herein contained shall prevent a seller rebutting the prima-facie case thus made by showing that his lower price ... was made in good faith to meet an equally low price of a competitor.

I5 U.S.C. \$ I3(b) (I994).

105 See, e.g., Conn. Gen. Stat. § 35-45 (I987); Utah Code ANn. § I 3-5-3 (I996).

106 In principle, the defense may be narrower under the FTC Act because section 5 has broader prohibitions than the Robinson-Patman Act. See supra note I7. No court has reached this issue yet, however.

107 See Standard Oil Co. v. FTC, 340 U.S. 23r, 234, 238-5I (I95I).

108 See HaRry L. Shinmerman, Price Discrimination In Perspective 79-80 (1977). Another widely cited commentator wrote, "In the famous Standard Oil of Indiana decision, the Supreme Court in 195 I authoritatively construed Section $2(\mathrm{~b})$ as providing a complete defense to a price discrimination charge, notwithstanding findings by the Federal Trade Commission of com- 
a reading is overly broad. The Supreme Court's 'reasoning in Standard Oil does not apply to primary-line cases, so its holding should be limited to similar secondary- and tertiary-line cases. ${ }^{109}$

r. Standard Oil. - Standard Oil arose because Standard Oil sold gasoline to certain large "jobbers"110 at a price $I \frac{1 / 2}{2}$ lower than the price it charged retail gas stations in the same region. ${ }^{111}$ These jobbers functioned simultaneously as wholesalers and as retailers: as retailers, they competed directly with the gas stations, and as wholesalers, some passed on these discounts to competing retailers (Figure 3 ). ${ }^{112}$ The net result of the discrimination was that some retailers had lower costs than others.

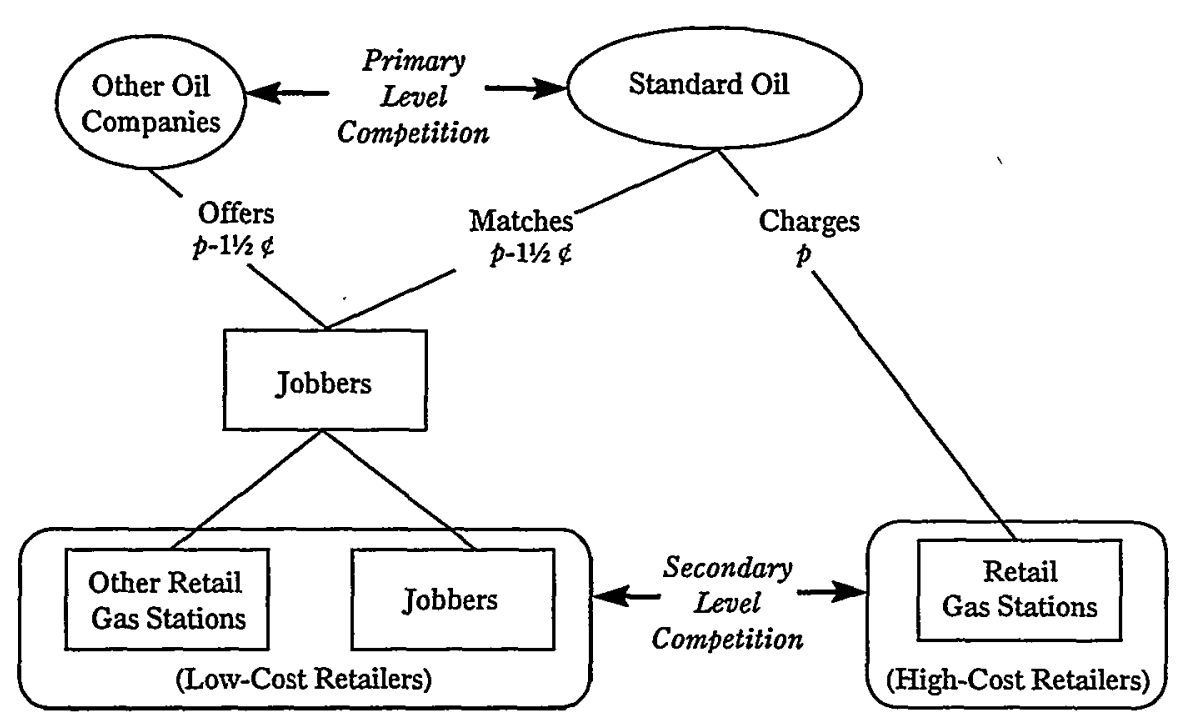

FIgURE 3. Standard Oil Co. v. FTC

petitive 'injury.'" Frederick M. Rowe, Price Discrimination Under the RobinsonPATMAN ACT 207 (Ig62).

109 Price-discrimination cases are categorized as primary line, secondary line, or tertiary line according to the level of competition injured by the discrimination. In a primary-line case, competition is injured among sellers, one or all of which discriminate in price. If competition is instead injured among buyers, the case is secondary line, and if the injury occursrstill further down the line of commerce, it is a tertiary-line case. See RowE, supra note IO8, at I4I, I72-73. Standard Oil was somewhere between a secondary-line price discrimination case and a tertiary-line case.

110 Jobbers resell gasoline to service stations and, in some cases, act as retailers themselves.

111 See Standard Oil, 340 U.S. at 235.

112 See id. 
Standard Oil defended its discriminatory pricing with the meetingcompetition defense set out in section $2(\mathrm{~b})$ of the Robinson-Patman Act. Other oil companies had also offered the jobbers low-priced gasoline, and Standard Oil was only matching these offers. The FTC nonetheless ordered Standard Oil to cease its price discrimination because retail gas stations that had to pay the undiscounted price for gasoline found it difficult to compete with stations that paid a lower price. ${ }^{113}$ The FTC maintained that the section 2(b) defense was a procedural provision, creating only a rebuttable presumption that the differential pricing was procompetitive. ${ }^{114}$ The Supreme Court, however, held that Standard Oil's meeting-competition defense could not be trumped. ${ }^{115}$ The Court allowed Standard Oil to discriminate on the ground that, even if there were some injury to competition among its customers, ${ }^{116}$ there was no apparent way to balance this injury against the enhanced competition among the oil companies from allowing Standard Oil to compete. ${ }^{117}$ As explained below, the Court's rationale

113 See id. at 233,235 .

114 See id. at 24I. Note that section 2(b) arguably appears to be procedural and was separated from the substantive defenses in section 2(a). The dissent in Standard Oil points out that, before the Robinson-Patman Act amended the Clayton Act, these defenses were together. See id. at 264 (Reed, J., dissenting). Section 2(b) can be read to allow a rebuttal to the prima facie case created by a showing of discrimination - a rebuttal that creates a requirement of more direct evidence of anticompetitive potential. Support for the FTC position is found in the Congressional Record: Representative Mell G. Utterback, chairman of the House conferees for the Robinson-Patman Act, said, "It is to be noted, however, that this does not set up the meeting of competition as an absolute bar to a charge of discrimination under the bill. It merely permits it to be shown in evidence. This provision is entirely procedural." 80 CoNG. REC. 9418 (I936) (statement of Rep. Utterback), quoted in Rowe, supra note I08, at 213 (emphasis added); see also Standard Oil, 340 U.S. at $264-67$ (Reed, J., dissenting) (arguing that the meeting-competition defense is procedural and that the FTC should be able to trump the defense with an affirmative showing of anticompetitive effects); 3 EARL W. KINTNER \& JOSEPH P. BAUER, FEDERAL ANTITRUST LAw: THE ROBINSON-PATMAN ACT $\S \mathrm{I9.9}$, at 264-67 ( $\mathrm{rg8}_{3}$ ) (providing historical background, some of which supports the FTC position); ROwE, supra note 108, at 208-I9 (discussing the origins of the meeting-competition proviso and the challenge to its status as an absolute defense to pricediscrimination charges).

115 See Standard Oil, 340 U.S. at 246.

116 The Court reasoned that the retail gas stations that paid a high price would have been equally disadvantaged if Standard Oil could not offer the jobbers a discriminatory lower price and the jobbers had bought from Standard Oil's competitors that had also offered the lower price: "[I]t must have been obvious to Congress that any price reductions initiated by a seller's competitor would, if not met by the seller, affect competition at the beneficiary's level or among the beneficiary's customers just as much as if those reductions had been met by the seller." Standard Oil, 340 U.S. at 250; see also General Shale Prods. Corp. v. Struck Constr. Co., 132 F.2d 425, 429 (6th Cir. r942) ("If appellant would not have been injured . . . by acceptance of the bid of either of the other two competitors of the [appellee], it could not have been injured by acceptance of a competing bid in the same amount by the [appellee].").

In fact, the Court suggested that, if Standard Oil could not offer the gasoline at the discriminatory low price, the consequence might be "ruinously raising its prices to its remaining customers to cover increased unit costs." Standard Oil, 340 U.S. at 250.

117 The Court concluded that, in the absence of more explicit requirements and more specific standards of comparison than we have here, it is difficult to see how an injury to competition at a 
only applies to a case in which the alleged competitive injury is to competition among buyers, as in a secondary-line price-discrimination case such as Standard Oil.

2. The Meeting-Competition Defense Applied to Price Matching. - The ruling in Standard Oil was based on the essential premise, never questioned by the Court or the FTC, that meeting a competitor's price is "beneficial" at the seller level.118 A primary-line case such as price matching differs starkly from Standard Oil, in that the very injury alleged challenges the Court's fundamental assumption that meeting the competition enhances competition among sellers. If a plaintiff alleges that a price matcher, through its matching policy, prevents rivals from competing with it and thereby lessens competition, it makes little sense to allow the price matcher to defend its policy without articulating a convincing argument that its policy is procompetitive. In Standard Oil, the Court allowed the meeting-competition defense only because it viewed meeting a competitor's price as an inherently desirable practice. The fundamental question, then, is whether meeting a competitor's price is an inherently competitive act. Part I argued that, despite appearances to the contrary, it is not.

Consider the analogy proposed in the introduction to this Article. Throughout the Cold War, both the United States and Soviet Union threatened to respond to an attack by the other with devastating force. Because nuclear war was deterred, the threat of destruction was not itself destructive. Likewise, if price-matching pledges discourage others from cutting prices, these pledges are anticompetitive, even if they promise a competitive price on their face. Meeting competition is not inherently competitive. If it discourages other firms from competing on price, and if the ability to meet competition encourages a firm to raise its own price, meeting competition is anticompetitive. There is no paradox in this conclusion. ${ }^{119}$

In Standard Oil, the Court, quoting A.E. Staley Manufacturing Co. v. FTC, ${ }^{120}$ reasoned that, in the Sherman, Clayton, and RobinsonPatman Acts, "Congress was dealing with competition, which it sought to protect, and monopoly, which it sought to prevent.'"121 The intent of putting the defense in the Robinson-Patman Act was specifically to foster competition at the primary level. ${ }^{122}$ Given this goal, the

level below that of the seller can be balanced fairly against a justification for meeting the competition at the seller's level. See id. at $25 x$.

118 See id.

119 It would be more paradoxical to assert that an act is competitive even though it impairs competition.

120 I35 F.2d 453 (7th Cir. 1943).

121 Standard Oil, 340 U.S. at 249 (quoting Staley, I35 F.2d at 455 ).

122 See EARI W. Kintner, A RobINSon-PATMAN PRIMER I78 (I970) ("This defense has the effect of sanctioning certain instances of discriminatory concessions and constitutes a congressional resolution of encouraging 'hard competition' - lower prices."). 
defense of meeting competition should not shield price matchers in cases in which their policies of discriminating between informed and uninformed customers weaken or destroy competition among sellers at the primary level. Courts should therefore limit the Standard Oil holding to secondary- and tertiary-line cases. ${ }^{123}$

Courts should not, however, eliminate the meeting-competition defense in all primary-line cases. The paradigmatic primary-line case alleges that a seller lowered its price below cost in one region predatorily to knock out its competitors there without incurring the costs of lowering price everywhere. ${ }^{124}$ Predation involves undercutting, not simply matching, the prices of the prey. ${ }^{125}$ Therefore, if the defendant can show that he was only meeting competitors' prices, ${ }^{126}$ the defense proves that the allegation of predation is false. The courts should accept such a defense. In contrast, in a price-matching case, the plaintiff contends that the meeting of competition involved in a price-matching pledge either lessens or prevents competition with the matcher. Asserting that the price matcher is merely meeting the competition does not defeat the substance of the accusation: to the contrary, it is part of the accusation.

Courts could therefore allow the defense in secondary- or tertiaryline cases ${ }^{127}$ and in primary-line cases of predation, but make the defense rebuttable or even categorically unavailable when the offense to

123 Limiting the Standard Oil holding to secondary- and tertiary-line cases would allow claims to be brought against price matchers for reducing competition at the primary level. It begs the question, though, whether the Court was correct to presume on the facts of Standard Oil that allowing Standard Oil to match competitors' bids enhanced competition among oil companies. The arguments in this Article suggest that the Court erred. Competition was presumably reduced by Standard Oil's matching behavior. If Standard Oil's policy was to meet any lower price offered to its customers, this policy would have discouraged other oil companies from trying to bid away Standard Oil's customers, and thereby would have allowed Standard Oil to raise its own prices without fear of losing the jobbers.

124 See Utah Pie Co. v. Continental Baking Co., 386 U.S. 685, 690-91 (1967); William Inglis \& Sons Baking Co. v. ITT Continental Baking, 668 F.2d IoI4, I024-25 (9th Cir. I98I); International Air Indus. v. American Excelsior Co., 517 F.2d 7I4, 718-19 (5th Cir. 1975); Balian Ice Cream Co. v. Arden Farms Co., 23I F.2d 356, 366 (gth Cir. r955). For discussion and more citations to primary-line cases, see Hugh C. Hansen, Robinson-Patman Law: A Review and Analysis, 51 FORDHAM L. REV. III3, II37-4I (I983).

125 See, e.g., Utah Pie, 386 U.S. at 690-91; William Inglis, 668 F.2d at 1035-36; Balian, 231 F.2d at 366; see also Phillip Areeda \& Donald F. Turner, Predatory Pricing and Related Practices Under Section 2 of the Sherman Act, 88 HARv. L. REV. 697, 724 (I975) (analyzing predatory pricing from an economic perspective); Paul L. Joskow \& Alvin $\mathrm{K}$. Klevorick, A Framework for Analyzing Predatory Pricing Policy, 89 YALE L.J. 213, 220-22 (r979) (noting the difficulty in distinguishing predatory and competitive price cuts).

126 The defense in section 2(b) of the Robinson-Patman Act is not available to those that beat the prices of their competitors, although accidental or good-faith beating of competitors' prices may be allowed. See, e.g., Jones v. Borden Co., 430 F.2d 568, 572-73 (5th Cir. 1970); Balian, 231 F.2d at 366; Beatrice Foods, 76 F.T.C. 7I9, 809-r2 (I969).

127 A case is "tertiary line" if the alleged or potential injury to competition is among buyers of the buyers among whom the price discrimination took place (for example, the gas stations that bought from jobbers who bought from Standard Oil). 
competition is not predatory pricing, but rather the removal of incentives to compete through prices. This proposal does not read the defense out of section 2(b) entirely, as some have asserted the FTC's position would have, ${ }^{128}$ nor does it conflict with the cases that follow Standard Oil. ${ }^{129}$ The argument to limit the meeting-competition defense has even more force if a price matcher is attacked under section 5 of the FTC Act or some state act that does not explicitly include a meeting-competition defense. Courts interpreting such an act would have no justification for inventing a meeting-competition defense so broad that it applies even when the act of meeting competition causes competitive injury without offsetting benefits.

3. The Meeting-Competition Defense Generally. - The arguments presented above for limiting the meeting-competition defense extend to contexts other than price-matching offers. For instance, consider a cartel that agrees to charge high prices and to split the market in some particular way. The cartel must find some way to maintain its agreement and discourage one firm from raiding the customers of another. One way a firm in the cartel can do so is to respond to raiding by lowering its own price to any customer the raider tries to attract. Even if not advertised in advance, such a practice might in some cases discourage raids. This will be particularly true if buyers, as in United States v. FMC Corp. ${ }^{130}$ have signed meet-or-release clauses, so that they are only released from their supply contracts if the supplier does not meet rivals' offers. ${ }^{131}$ Meeting competitors' prices on an offer-byoffer basis can be a highly credible way to discourage competition because it is much cheaper than lowering prices to all. Antitrust law should not view such a practice as procompetitive.

\section{B. Is Price Discrimination the Culprit?}

Price-discrimination laws ban only discrimination that causes anticompetitive effects. ${ }^{132}$ This section pins down the legal connection between the discriminatory aspects of price matching and the potential of price matching to reduce competition.

To understand why price discrimination is at fault, consider the causal link in a typical predatory price-discrimination case such as

\footnotetext{
128 See Rowe, supra note I08, at 2 I8 ("The Commission's theory erased the meeting competition proviso from the statute.").

129 The proposal would not affect the use of the defense in secondary-line cases, nor in primaryline cases involving predation, which constitute all the primary-line cases I have found in which the defense is used. See, e.g., cases cited supra note I24; SHNIDERMAN, supra note IO8, at 27-33; Hansen, supra note I24, at II37-42. As argued above, the defense legitimately rebuts a predation charge.

130306 F. Supp. I I06 (E.D. Pa.'Ig69).

131 See supra note 5.

132 See, e.g., I5 U.S.C. § I3(a) (1994).
} 
Atlas Building Products Co. v. Diamond Block \& Gravel Co. ${ }^{133}$ In that case, Atlas Building Products sold cinder blocks at lower prices in Las Cruces, New Mexico, where it competed with Diamond Block \& Gravel, than in El Paso, Texas, where it had a "virtual monopoly."134 Although the court found that this discrimination violated the Robinson-Patman Act, observe that Atlas's price discrimination could not have directly caused any harm to Diamond, the competitor in Las Cruces. Diamond would have had just as difficult a time competing with Atlas if Atlas, instead of charging discriminatory prices, had charged equally low prices in El Paso, where Diamond did not operate.

The link between the discrimination and the harm comes from the behavioral hypothesis implicit in the Robinson-Patman Act: namely, Atlas would have been more hesitant to lower its prices everywhere than to offer selective discounts. ${ }^{135}$ Thus, if discrimination were illegal, Atlas very likely would not have lowered its prices in Las Cruces to predatory levels, because this reduction would have required a costly general price reduction. The same link is present in a pricematching case. If price-matching policies were illegal, a firm confronted with a price cutter would have to lower prices to every buyer to keep the business of its informed buyers. ${ }^{136}$ Price matchers might not be willing to make a general price reduction. As section I.E explains, they might prefer to profit from uninformed buyers than to match a price reduction for all buyers immediately. If price cuts will not be matched, competitors have an incentive to cut their prices in pursuit of short-term gains. Competition may then drive down prices. This chain of reasoning demonstrates the integral role that price discrimination plays in the anticompetitive power of price matching. ${ }^{137}$

\section{What Anticompetitive Power Remains If Firms Cannot Substitute Matching Offers for Actual Price Reductions?}

One objection to the approach of this Article is that, although the two legal theories it proposes may be adequate to address promisebased matching offers, they do nothing to deal with closely related matching strategies, which may have similar economic effects in some

\footnotetext{
133269 F.2d 950 (Ioth Cir. I959).

134 Id. at 953 .

135 The court wrote that "it is fairly inferable that the appellant [Atlas] utilized its higher El Paso prices to stifle competition with its lower prices in the Las Cruces area." Id. at 956.

136 See supra section I.E.

137 Also consider the theoretical argument given in Part I that discrimination causes market prices to rise. Recall that in cases in which price-matching policies do not discriminate, that is, in which all customers are informed, these policies need not cause prices to rise. The competitive equilibrium in section I.B was only broken by price matchers raising prices to discriminate against the uninformed.
} 
cases. ${ }^{138}$ In particular, neither the vertical-agreement theory nor the price-discrimination theory could stop sellers from simply pricing in parallel: that is, lowering their posted price to match the price reductions of competitors ("threat-based matching").139 One question then arises: what is left of the anticompetitive power of matching strategies if a seller must actually reduce its posted price instead of substituting a matching offer? This question has ever-increasing salience because unilateral threat-based matching strategies may pose a more serious threat to competition as computers and computer networks become more sophisticated and information becomes cheaper to transfer and process.

Suppose that, whenever one firm lowers prices, its rivals react without any agreement by instantaneously lowering their prices by just enough to maintain market share: in other words, by matching price drops. Under this scenario, there will not be an agreement on which to hang a section I attack because these policies are being pursued wholly unilaterally, nor will there be price discrimination to attack under section 5 of the FTC Act or the Robinson-Patman Act. Yet, in principle, such "threat-based" matching policies can maintain high prices without the need for complex supergame strategies. ${ }^{140}$ Section I.E of this Article pointed out several disadvantages of threat-based matching vis-à-vis promise-based matching. Threat-based matching could be less effective because monitoring other firms' prices may be costly or slow and because a firm might not actually want to follow another firm down the price ladder if it were more profitable to take advantage of uninformed buyers at higher prices than to vie for the business of informed buyers at lower prices. Moreover, threat-based matching provides no obvious way either to raise prices to high levels in the first place without communication ${ }^{141}$ or to restore high prices after a price war. ${ }^{142}$

138 Professor Barry Nalebuff was the first to emphasize this point to me. See Telephone Conversation with Barry Nalebuff, Professor, Yale School of Management (Spring 1993).

139 See supra section I.E.

140 See POSNER, supra note $3 I$, at $42-43$; see also Stigler, supra note $3 I$, at 42 (explaining that fixing market shares will eliminate all incentives to undercut the market price). The necessary provision, of course, is that detection and matching of price reductions be immediate. When price reductions are not immediate, matching will not support a high price equilibrium. In that case, complex supergame strategies will do so if price reductions are sufficiently quick. See TIROLE, supra note 22 , at 239-76 (discussing the Folk theorem). Such strategies would involve more intense price wars and require considerable coordination among firms. These strategies also might suffer from problems with renegotiation. See Joseph Farrell \& Eric Maskin, Renegotiation in Repeated Games, I GAMES \& ECON. BEHAV. 327, 327-60 (1989); Joseph Farrell, Renegotiation in Repeated Oligopoly Interaction 3 (April ro, 1994) (unpublished manuscript, on file with the Harvard Law School Library).

141 See PoSNER, supra note $3 \mathrm{I}$, at 46 ("The interdependence theory does not explain, however, how oligopolistic sellers ever establish [prices above the competitive level] in the first place.").

142 Restoring high prices after a price war is particularly important when demand varies and firms do not directly observe each others' prices. In such cases, even if firms agree to collude and 
These disadvantages of threat-based matching are less important, however, when trading takes place on computerized exchange systems, such as NASDAQ, or when prices are accessed through a common computerized database such as the one run by the Airline Tariff Publishing Company (ATPCO). ${ }^{143}$ In these markets, sellers can easily monitor each other's prices. Moreover, the threat to follow others' price drops is credible because there are few uninformed buyers that will pay a higher price once some other firm offers lower prices. ${ }^{144}$ Robert Anderson has developed a notion of a "perfect quick-response equilibrium" and argued that threat-based matching strategies can sustain high prices when responses are sufficiently cheap and quick, as they are now, or will soon be, on computerized trading systems. ${ }^{145} \mathrm{Fi}-$ nally, observe that, because prices are readily observable on computerized trading systems, price wars cannot be precipitated by wrong inferences about cheating caused by low demand. ${ }^{146}$

These observations suggest a resistance to downward price movements under threat-based matching, but this still leaves an aspiring cartel with the problem of climbing the price ladder without explicit agreement. However, computerized markets may make it easier to surmount this difficulty as well. If prices can be adjusted and monitored quickly and costlessly, one firm may signal another of its desire to collude. For instance, airlines commonly test new high prices on weekends, when few buyers purchase tickets, and maintain them if others follow their lead. ${ }^{147}$ In principle, the computer age may mean that such "tests" could last for only seconds, and thus the price leader loses little demand even if it is not followed. In light of these observations, a serious challenge to antitrust is posed by the increasing amount of trade that takes place on the Internet and on more standard closed

charge high prices, they will eventually end up in a price war because their demand is unusually low and they infer wrongly that others have secretly undercut their price. See, e.g., TIROLE, stupra note 22, at 262-64 (discussing the Green-Porter model).

143 See Marj P. Leaming, Enlightened Regulation of Computerized Reservations Systems Requires a Conscious Balance Between Consumer Protection and Profitable Airline Marketing, $2 \mathrm{I}$ TRANSP. L.J. 469, 474-77 (I993) (describing ATPCO and its relationship to the airlines' computer reservation systems).

144 Recall that the reason a threat to match price reduction might not be credible is that a firm might prefer to continue to "take advantage" of uninformed buyers by charging them high prices than to reduce prices for everyone. See supra pp. 551-52.

145 Robert M. Anderson, Quick-Response Equilibrium I2-I7 (I985) (unpublished manuscript, on file with the Harvard Law School Library). The mathematically inclined reader will profit immensely from reading Anderson's paper. See id. at I3 (defining quick-response equilibria); $i d$. at I9-22 (discussing oligopoly theorems).

146 See supra note $\mathrm{I}_{42}$ (discussing price wars when prices are unobservable).

147 See In re Domestic Air Transp. Antitrust Litig., r993-I Trade Cas. (CCH) Il 70, 165, at 69, 766-67 (N.D. Ga. 1993); see also Keith L. Alexander, Airlines Raise Ticket Prices $5 \%$ After All, USA TODAY, Sept. 10, I997, at Br (noting that, by changing its fares on a weekend, an airline can test whether its competitors will follow suit before travel agencies see the new fares on their computer systems). 
systems, such as NASDAQ or the airlines' computer reservation systems. Thus, even if promise-based price-matching policies are banned on the basis of the vertical-agreement or price-discrimination theories, threat-based matching may come to cause many of the same harms with entirely unilateral action. ${ }^{148}$

The anticompetitive danger posed by threat-based matching is not so dire, however, as to justify Congress's eliminating the agreement requirement from section $I$. Using prices as signals to collude with rivals may be difficult to implement in many markets. No matter how quickly firms can adjust prices, they still lose business by charging high prices unless they use promise-based matching so as effectively to charge low prices to the informed. ${ }^{149}$ If one firm tries to lead a charge toward high prices, other firms will be tempted to delay following suit, believing that they will not affect the ultimate success of the venture and profiting by continuing to charge low prices while others charge high prices. Coordinating a price move may be hopeless, even in the

148 This possibility raises an important question: should either Congress or the courts abandon section I's agreement requirement in order to pursue threat-based matching and make antitrust more effective? Richard Posner, for instance, argued more than two decades ago that courts should put an end to the "cops-and-robbers" approach to price fixing and instead base findings of section I illegality on an economic analysis of the market, inferring a tacit agreement whenever there is a bad economic outcome. See PoSNER, supra note $3 I$, at $7 \mathrm{I}-76$. Many object to this proposal, fearing that section I would then ban all unreasonably high prices and turn courts into regulatory agencies with expansive jurisdiction, an unpopular proposition in an era in which capitalist and communist governments alike are racing to deregulate and eliminate centralized price administration.

Abandoning the agreement requirement, however, need not imply straightforward price regulation. A more limited, albeit radical, approach is to make it illegal to follow others down the price ladder. This approach follows naturally from this Article's analysis of threat- and promisebased matching. If other firms cannot match a price cutter, at least for some time, the price cutter can profit from undercutting his rivals. Sealed-bid auctions also have this feature, because one firm cannot adjust its bid in response to the bids of others. This restriction restores the incentive to cut prices when they exceed cost. Also, because firms will fear being undercut, they will have an incentive to price low at the outset. An important practical problem with this approach is determining how long a firm should be forced to commit to a price. Presumably, the commitment time should depend on factors specific to each market, such as the speed with which customers shift to a low-priced firm or the variability of input prices.

Courts are ill-suited to undertake such market micromanagement. Moreover, even if they could manage it, this approach has little legal foundation. Although the government has the power and responsibility to lay the ground rules for markets, the Sherman Act is not a legislative carte blanche for the courts, and most of this power remains with the legislature. The courts should therefore continue to require evidence of agreements until and unless Congress mandates otherwise.

149 Firms may make such signaling easier through other methods. For instance, Tweeter, Etc., a consumer electronics firm in New England, will automatically send refund checks to buyers if others charge less. See William M. Bulkeley, Tweeter's Customers Told: 'Your Check Is in the Mail', WALl ST. J., Aug. I7, I993, at B6. Such a promise-based matching policy can allow a firm to post a high price that takes effect only if others take the hint. As trade moves to electronic networks, implementing such a policy may become easier. 
computer age, if the market is sufficiently fragmented and there is no express agreement. ${ }^{150}$

Only the future will tell whether focusing on agreements or price discrimination is sufficient in the computer age to avert anticompetitive outcomes. If it is not, the government may need to foster competition by setting up markets with carefully crafted bidding rules. On the other hand, competition may again come to the rescue. Competition may emerge on its own in computerized exchange systems. Each system will have its own rules, and if a rule such as requiring firms to commit to posted prices proves efficient by bringing prices toward cost, systems adopting this rule would attract buyers and could charge them for the privilege of buying at competitive prices. ${ }^{151}$ The question is whether sellers could be bribed to compete.

\section{Concluston}

The advertisement by the Campus Textbook Exchange has it right: "Saying 'we will match any price' only means their prices are too high to begin with." 152 When Circuit City advertises that "you can't get a lower price - we guarantee it!" their claim may be true - not necessarily because their prices are truly low (that is, close to cost), but rather because they will lower their price to any buyer offered a lower price elsewhere. ${ }^{153}$ These policies can potentially lead to supracompetitive prices even in markets with low entry barriers, and the social cost of persistent high prices in these markets could be substantially higher than in monopolized markets. In markets with only a few firms, anticompetitive results seem particularly likely.

Price-matching policies raise several difficult doctrinal challenges for antitrust law. Because price matching facilitates "collusive" outcomes without any collusion, tacit or explicit, bringing a case under the Sherman Act might prove difficult. Nonetheless, such a case might be based on the vertical agreement between a buyer and seller to match another seller's price. Such a focus is consistent with the modern rule-of-reason approach delineated by Justice Brandeis in Chicago Board of Trade v. United States, ${ }^{154}$ in which the "true test of legality is whether" an agreement "promotes competition ... or de-

\footnotetext{
150 On the other hand, in concentrated markets such as airline travel, coordinating price increases seems common. See supra p. 569.

151 Ironically, a system adopting such a rule might well be subject to scrutiny under section I of the Sherman Act.

152 Campus Textbook Exchange, supra note 4. However, when telephoned about their advertisement, the store's manager assured the author that they too would match prices.

153 Circuit City, Advertisement, KGO-TV television broadcast, July 3I, 1997.

154246 U.S. 23 I (19I8).
} 
stroy[s] competition."155 Thus, effect, and not intent, should be determinative.

Because price matchers implicitly offer to sell at a discount to an informed buyer, or to a buyer lucky enough to have been offered a lower price elsewhere, price-matching policies might also violate state or federal laws banning price discrimination or unfair methods of competition. Although the meeting-competition defense appears to serve as an impediment to applying these laws, the leading case establishing this defense as absolute is not entirely on point, because its arguments apply only to secondary-line cases in which the alleged competitive injury is to the competition among buyers, not sellers. Price matchers should be required to defend their practice by arguing directly that their policies enhance competition instead of diminishing it. Although this common-sense conclusion is a break from what scholars presume to be the existing doctrine, it is perfectly consistent with Standard Oil and its progeny. The main legal question is the same as the economic question: are these policies anticompetitive in effect?

Some authors have argued that, in long-term contracts, pricematching clauses may provide efficient price flexibility by ensuring that contract prices track the spot market price. ${ }^{156}$ This argument has merit as long as the spot market price is efficient and alternatives such as relying on renegotiation would be costly. Such an argument does not, however, apply to the spot markets for two reasons. First, the policies themselves may make spot market prices inefficient. Second, if the goal is to have low prices today, a surer method would be to simply charge low prices, as the Campus Textbook Exchange advertisement suggests. In fact, no one has presented a convincing argument that these policies are procompetitive in spot markets. Corts and Hviid and Shaffer come closest by arguing that the approach of this Article exaggerates the anticompetitive potential of price matching. ${ }^{157}$ Even if one accepts their analyses, however, ${ }^{158}$ their work hardly provides a ringing endorsement of price matching, because it does not identify any benefits. In fact, although Hviid and Shaffer emphasize that prices will not reach monopoly levels when there are hassle costs, they acknowledge that prices can still be substantially above competitive levels. ${ }^{159}$

Antitrust cases are invariably complex, and one can rarely decide with much certainty whether a practice is procompetitive or anti-

155 Id. at 238.

156 See Keith J. Crocker \& Thomas P. Lyon, What Do "Facilitating Practices" Facilitate? An Empirical Investigation of Most-Favored-Nation Clauses in Natural Gas Contracts, 37 J.L. \& ECON. 297, 320 (r994); Simons, supra note II, at 600, 639.

157 See Corts, supra note 9, at 4r9-20; Hviid \& Shaffer, supra note 24, at 2.

158 See supra note 24 (criticizing this argument).

159 See Hviid \& Shaffer, supra note 24, at 22 (providing examples derived from a model in which prices rise up to $36.4 \%$ if hassle costs are extremely low). 
competitive in any given instance. ${ }^{160}$ One may point to a market in which price matching was introduced and assert that prices rose, as Hviid and Shaffer suggest happened in two camera and sporting-goods markets, ${ }^{161}$ as Hess and Gerstner suggest happened among North Carolina supermarkets, ${ }^{162}$ as Grether and Plott ${ }^{163}$ suggest happened in E.I. du Pont de Nemours \& Co. v. FTC, ${ }^{164}$ and as numerous researchers suggested happened on NASDAQ. ${ }^{165}$ However, defendants will always argue, sometimes correctly, that such a price rise might be due to other factors. Under the Robinson-Patman Act, the issue is somewhat simplified by the fact that no proof of actual anticompetitive effect is necessary to violate the Act, only the "reasonable probability" or "reasonable possibility" of such an effect.166 From a public-policy perspective, the more lenient standard of the Robinson-Patman Act may

160 This discouraging fact is one of the rationales for per se rules.

161 See Hviid \& Shaffer, supra note 24 , at 24.

162 See James D. Hess \& Eitan Gerstner, Price-Matching Policies: An Empirical Case, 12 MaNAGERIAL \& DECISION ECON. 305, 3II-I3 (I991).

163 See David M. Grether \& Charles R. Plott, The Effects of Market Practices in Otigopolistic Markets: An Experimental Examination of the Ethyl Case, 22 ECON. INQUIRY 479, 49I-97, 499 (I984).

164729 F.2d 228 (2d Cir. I984).

165 William Christie and Paul Schultz generated a storm of media attention in 1994 when they suggested that "tacit collusion" by market makers on NASDAQ widened bid-ask spreads above competitive levels by avoiding odd-eighth quotes on a number of securities. See William G. Christie \& Paul H. Schultz, Why Do NASDAQ Market Makers Avoid Odd-Eighth Qnotes?, $49 \mathrm{~J}$. FIN. I813, 1838-39 (I994); William G. Christie, Jeffrey H. Harris \& Paul H. Schultz, Why Did NASDAQ Market Makers Stop Avoiding Odd-Eighth Quotes?, 49 J. FIN. I84I, I858-59 (I994); see also William G. Christie \& Paul H. Schultz, Policy Watch: Did NASDAQ Market Makers Implicitly Collude?, 9 J. ECON. PERSP. 199, 20I-03 (1995) (describing the discovery of the evidence of tacit collusion).

The Department of Justice and the Securities and Exchange Commission both investigated the practices on NASDAQ and concluded that the market makers were committed to a complex price-fixing agreement, which involved avoiding odd-eighth quotes and thereby frequently keeping the inside spread at one-quarter point or higher on over-the-counter stocks traded through NASDAQ. Department of Justice, Competitive Impact Statement in U.S. v. Alex. Brown E Sons Inc. I2-I6 (July I7, I996); Securities and Exchange Commission, supra note 7, at 14-15.

Critics have argued, however, that it is implausible that a price-fixing scheme could result in high prices in a market like NASDAQ, with many competitors and over Ioo potential entrants. See Kleidon \& Willig, supra note 32 , at 6-8.

Price matching, however, was pervasive among NASDAQ market makers and provides an answer to these critics. Under standard practice, market makers would buy stock at the highest quoted bid and sell it at the lowest quoted ask, even if they themselves were quoting a lower bid or higher ask. Department of Justice, supra, at 8-1I; Securities and Exchange Commission, supra note 7 , at $\mathrm{I}_{5}$. As this Article has demonstrated, pervasive price matching could dramatically lower or even eliminate a market maker's incentive to cheat on a price-fixing agreement by quoting an odd-eighth and reducing a high spread, even when there are, as Kleidon and Willig emphasize, many competitors and many potential entrants. See Edlin \& Emch, supra note 6, at 2429 (detailing NASDAQ practices, the econometric evidence about spreads, and the potential impact of price matching on spreads).

166 There has been a great deal of confusion in the case law about whether the proper standard under the Robinson-Patman Act is a reasonable possibility or a reasonable probability of competitive injury. See ShNmERMan, supra note 108, at 24-25 (listing cases). 
be the right one under which to judge price matching. After all, competition appears to work well both in theory and in practice without matching policies; thus, the benefits of the policies must be limited. The potential harms, on the other hand, are substantial. Has the time come to ban such policies? It is a possibility that should be taken seriously.

\section{APPENDIX}

This Appendix generalizes the oil-change example from the text in two ways. ${ }^{167}$ Section A shows that not all firms need to be price matchers if the proportion of informed buyers depends on the price dispersion. Section B shows that the monopoly-pricing result holds for arbitrary demand functions. This Appendix relaxes only one assumption at a time.

\section{A. Endogenous Search}

If the number of customers that choose to become informed is not exogenous, but instead depends on the amount of price dispersion (that is, the degree to which prices differ among sellers), then the monopoly price equilibrium may occur even when only some firms are price matchers. To see this, observe first that in a monopoly price equilibrium, price dispersion is zero. If one firm cuts prices and thus slightly increases the amount of price dispersion, it may not induce enough new searches to justify the price cut, even if few of its competitors are price matchers. In the extreme case where the price cut induced no search, the price cut would be unprofitable even if no other firms match prices.

Now consider the less extreme case. To begin, suppose all $N$ firms are charging the monopoly price of $\$ 30$ and $N_{p m}$ of them have pricematching policies. A single firm considers lowering its price by an amount $d$ that is greater than zero. Let $a(d)$ be the fraction of buyers who choose to search and become informed. Assume that $a(0)=0$ and $a^{\prime}(d)>0$ (where $a^{\prime}(d)$ is the first derivative of $a(d)$ ), so that customers do not compare prices if prices are identical, but more customers choose to become informed the more prices vary. If there are $L$ customers in total, then the firm considering lowering its prices will get demand of $L[1-a(d)] / \mathrm{N}$ (non-searchers) $+L a(d) / N_{p m}$ (searchers). Using a Taylor series expansion, we find that the percentage increase in the number of customers from a small price drop $d$ is $\left\{\left[L d a^{\prime}(0) / N_{p m}\right]-\left[L d a^{\prime}(0) / N\right]\right] /(L / N)$. If we divide this quantity by the percentage price change $(d / \$ 30)$, we get the firm's demand elasticity: $e=(\$ 30) a^{\prime}(0)\left[\left(N / N_{p m}\right)-1\right] . .^{168}$ A firm will

${ }^{167}$ See Edlin \& Emch, supra note 6, at 6-15 (providing a still more general and thorough treatment).

168 See CARLTON \& PERLOFF, supra note 32, at 98-99 (defining demand elasticity). 
profit from a small price cut if its percentage markup $z$, where $z=$ (price-marginal cost)/price, is greater than (1/e).169 In this case, it profits if $\$ 3 \circ a^{\prime}(0)\left[\left(N / N_{p m}\right)-1\right]>1 / z$, or equivalently if $N_{p m}<N /\{1+$ $\left.1 /\left[(z)(\$ 30) a^{\prime}(0)\right]\right]$.

Note that this situation is only an equilibrium if the price cut is not profitable. Recall that $a^{\prime}(0)$ measures the responsiveness of search to price dispersion. If $a^{\prime}(0)$ is very large, so that the possibility of getting a slightly lower price motivates a huge amount of search, then the monopoly price equilibrium requires all firms to match prices: if even a single firm did not match, then the above inequality would hold and thus indicate that other firms could profit by lowering their prices. On the other hand, if $a^{\prime}(0)$ is small, the equilibrium has more slack. In that case, if several firms do not have matching policies, it still will not be profitable to lower prices to attract their customers, because too few will search and actually be attracted. In the extreme case where $a^{\prime}(0)=0$ and thus a price drop prompts no search, price matching is not necessary to discourage price cuts. Other articles provide more thorough analyses of price matching in a search model. ${ }^{170}$

\section{B. General Demand}

Suppose demand were not inelastic, but were downward sloping and given by some function $d(p)$. Does this change the results? Assume that the monopolist produces with fixed $\cos t s F$ followed by constant marginal cost $c$. In maximizing the excess of revenues above costs, such a monopolist would choose monopoly price $m$ to maximize $d(p)(p-c)$, the profits made from each customer. Assume that the price $m$ is unique. This situation is much as in the example in the text.

Now consider what will happen if many firms enter this market. Assume as in the text that market share is determined entirely by the effective price charged (rather than by location, service, and so forth). Let $p_{\text {low }}$ denote the lowest posted price. A firm posting $p_{\text {low }}$ has profits of $-F+\left(p_{\text {low }}-c\right) d\left(p_{\text {lovo }}\right) a L / N_{\text {loov }}+\left(p_{\text {low }}-c\right) d\left(p_{\text {lovo }}\right)(1-a) L / N$, where $a$ equals the percentage of informed customers, $L$ equals the number of customers, $N$ equals the number of firms, and $N_{\text {low }}$ equals the number of firms either charging the lowest price or not charging the lowest price but adopting a matching policy.

If $p_{\text {low }}$ is less than the monopoly price $m$, the firm can make more money from the (1-a)L/N uninformed customers by raising its price from $p_{\text {low }}$ to $m$. By becoming a price matcher, the firm can raise its price without sacrificing its profits from its informed customers. Such a strategy would give the firm profits of $-F+\left(p_{l o 00}-c\right) d\left(p_{\text {low }}\right) a L / N_{\text {loot }}+(m-$

169 See id. at $136-37$ (deriving this result).

170 See Aaron S. Edlin, Price Matching, A Ploy for Price Discrimination, Resuscitates the Law of One Price I2-I5 (May 1990) (unpublished manuscript, on file with the Harvard Law School Library); Edlin \& Emch, supra note 6, at 6-15. 
c) $d(m)(1-a) L / N$, which we know exceeds the profits calculated above because the construction of $m$ implies that the second term is larger than the second term in the previous expression for profits. ${ }^{171}$ Again, the only equilibrium is for all stores to charge the monopoly price $m$.

171 This formula assumes that the low price is below the price $m$. If it is not, the improvement would be still larger because more money would be made off both the informed and the uninformed by lowering prices to $m$. 